Savunma Bilimleri Dergisi

The Journal of Defense Sciences

Kasim/Nov 2018, Cilt/Volume 17, Say1/Issue 2.

ISSN (Bas1l1) : 1303-6831 ISSN (Online): 2148-1776

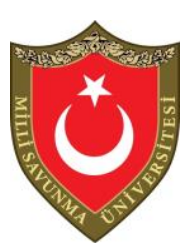

\title{
Türk Deniz Kuvvetleri Açısından Uçak Gemisi Tedarikinin İncelenmesi
}

\author{
Cenk ÖZGEN*
}

$\ddot{O} z$

Türk Deniz Kuvvetleri tarafindan yürütülen Çok Maksatl Amfibi Hücum Gemisi Projesi kamuoyunun yoğun ilgisini çekmektedir. Proje, esas amacı çıkarma harekâtlarının icrası olan Havuzlu Helikopter Gemisi sınıfinda bir platformun tedarikini öngörmektedir. Ancak projeyi asıl öne çıkaran tarafi söz konusu platformun Kısa Mesafeden Kalkış ve Dikey İniş yeteneği haiz uçakların da harekâtına imkân tanıması dolayısılla gerektiğinde uçak gemisi görevlerini de icra edebilmesidir. Tedarik edilecek platformun uçak gemisi rolünü üstlenebilmesi Türk Deniz Kuvvetleri'nin böyle bir yeteneğe ihtiyacı olup olmadı̆̆ına ilişkin tartışmalar beraberinde getirmiştir. Nitekim bir görüş uçak gemisi tedarikini desteklerken, diğerinin karşı çıktığı görülmektedir. Bu çalışma, Türk Deniz Kuvvetleri'nin harekât ihtiyaçları kapsamında uçak gemisi tedarikinin incelenmesini amaçlamaktadır. Çalışmada, uçak gemisi tedarikinin gerekliliği üzerinde durulmakta ve Çok Maksatlı Amfibi Hücum Gemisi Projesi'nin yerinde bir adım olduğu vurgulanmaktadır. Yine çalışmada, bir sonraki aşamada Türk Deniz Kuvvetleri'nin klasik uçak gemisi tedarikini de gündeme alması gerektĭgi savunulmaktadir.

Anahtar Kelimeler: Türk Deniz Kuvvetleri, Uçak Gemisi, Amfibi Hücum Gemisi, TCG Anadolu, TF-X Deniz.

\footnotetext{
* Dr.Öğr.Üyesi, Giresun Üniversitesi, İktisadi ve İdari Bilimler Fakültesi, Siyaset Bilimi ve Kamu Yönetimi Bölümü, cenk.ozgen@giresun.edu.tr 


\title{
An Examination of Aircraft Carrier Procurement from the Perspective of Turkish Naval Forces
}

\begin{abstract}
The Multi-Purpose Amphibious Assault Ship Project carried out by the Turkish Naval Forces has intensively attracted public attention. The Project has foreseen the procurement of a Landing Helicopter Dock class of vessel, which primarily focuses on landing operations. On the other hand, the most interesting point about the ongoing project is the vessel's suitability for deployment of aircrafts capable of Short Take-Off and Vertical Landing and therefore, its potential to serve as aircraft carrier. Landing Helicopter Dock is being associated with aircraft carrier role, has been brought along with intensive discussions about the necessity of this type of vessel for the Turkish Naval Forces. Thus, one part expresses support for aircraft carrier procurement, while other part rejects. This study aims to examine the procurement of aircraft carrier within the scope of operational requirements of the Turkish Naval Forces. Necessity of aircraft carrier acquisition and propriety of the Multi-Purpose Amphibious Assault Ship Project have argued in the study. Furthermore, necessity of procurement of classical aircraft carrier for the Turkish Naval Forces in the future has also argued in the study.
\end{abstract}

Keywords: Turkish Naval Forces, Aircraft Carrier, Amphibious Assault Ship, TCG Anadolu, TF-X Maritime.

\section{Giriş}

Son y1llarda Türk Deniz Kuvvetleri'nin uçak gemisine ihtiyacı olup olmadığına ilişkin tartışmaların yazılı ve görsel basında geniş yer teşkil ettiği gözlemlenmektedir. Aslında bu alandaki tartışmaların geçmişi 1990'lı yılların ortalarına kadar uzanmaktadır. Ancak konunun kamuoyunun gündemine girmesi Çok Maksatlı Amfibi Hücum Gemisi Projesi'nin başlaması, özellikle de Cumhurbaşkanı Recep Tayyip Erdoğan'ın muhtelif platformlarda uçak gemisine sahip olmanın önemine ve Türkiye'nin bu alandaki eksikliğine dikkat çeken açıklamaları sonrasında gerçekleşmiştir (Milliyet, 2016; Sabah, 2016; Hürriyet, 2017). 
Bugün Türkiye'de uçak gemisi üzerine tartışmaların iki karşıt görüş etrafında toplandığını söylemek mümkündür. Buna göre görüşlerden ilki uçak gemisi tedarikini desteklerken, diğeri karşı çıkmaktadır. Örneğin gazeteci Hakan Çelik (2013), Türkiye'nin ilgilendiği bölge ve çıkar alanlarının artık yakın coğrafya ile sınırlı olmadığını dolayısıyla uçak gemisi tedarikine müspet yönde yaklaştığını ifade etmektedir. Buna mukabil gazeteci Can Ataklı (2017) üç tarafı denizlerle çevrili durumdaki Anadolu'nun kendisinin zaten bir uçak gemisine benzediğini, emperyalistlerin ilgi alanına giren ve ülke savunmasına değil, uzak coğrafyalarda savaşmaya hizmet eden bu tip platformların Türkiye açısından "pahalı bir oyuncaktan" farkı olmayacağını düşünmektedir. Türkiye'nin daha acil ihtiyaçlarına vurgu yapan savunma sanayii araştırmacısı Hakan Kılıç'da (2018) şu aşamada uçak gemisi tedarikini gereksiz bulanlardandır. Burada ilginç olan husus benzer görüş ayrılığının bahriye kökenli denizciler arasında da yaşanmasıdır. Örneğin Emekli Tümamiral Cem Gürdeniz (2017), Türkiye'nin bir deniz ülkesi olduğunu, siyasi ve ekonomik alandaki gelişmelerin yeni hedef ve yetenekleri gündeme getirdiğini belirtmektedir. Gürdeniz'e göre 21. yüzyılda Türkiye'nin bulunduğu coğrafyada tutunabilmesi için caydırıcı ve güçlü bir donanmaya sahip olması gerekmektedir. Uçak gemisi ise sadece bu amaca hizmet etmekle kalmayıp Türkiye'nin denizcileşmesinin en önemli araçlarından biri hatta "lokomotifi" olacaktır. Buna karş1lık Emekli Tümamiral Soner Polat (2017), Türkiye'nin emperyalist devletler gibi denizaşırı hayati çıkarları bulunmadığını ve mevcut tehditler dikkate alındığında kaynakların uçak gemisi yerine hava kuvvetlerine sarf edilmesinin caydırıcılık açısından daha doğru olacağını savunmaktadır. Polat'a göre şartlar değişirse elbette yeni bir değerlendirme yapılabilir. Ancak mevcut koşullarda Türkiye, uçak gemisini ancak bir ittifak sistemi içerisinde etkin olarak kullanabilecektir. Bunun ise Türkiye'den ziyade başka ülkelerin çıkarlarına hizmet edeceği aşikârdır.

Uçak gemisi tedarikini savunanlar da karşı çıkanlar da iddialarını destekleyecek kuvvetli gerekçeler öne sürmektedirler. Kuşkusuz Türk Silahlı Kuvvetleri (TSK) ve bilhassa Deniz Kuvvetleri Komutanlığı (Dz.K.K.lığı) bünyesinde konuyu ele alan kapsamlı çalışmalar yapılmaktadır. Ancak bazı yüzeysel çalışmalar dışında sivil kesim, özellikle de akademik çevreler için aynısını söylemek mümkün değildir. Aslında bu durumun uçak gemilerine özgü bir 
durum olmadığı ortadadır. Türkiye'de savunma politikaları, stratejileri ve teknolojileri üzerine çalışan sınırlı sayıda akademisyen vardır. Kaldı ki bu alanlarda çalışan sınırlı sayıdaki akademisyenin de büyük bölümü asker kökenlidir.

Bir donanmanın kuvvet yapısına uçak gemisinin dâhil edilmesi herhangi bir savaş gemisinden farklı anlamlar taşımaktadır. Nitekim akademik alandaki boşluk da göz önünde bulundurulduğunda konunun tüm boyutlarıyla ele alınması gereği ortaya çıkmaktadır. Bu tespitten hareketle Türk Deniz Kuvvetleri'nin harekât ihtiyaçları kapsamında uçak gemisi tedarikini incelemeyi amaçlayan çalışma dört bölümden oluşmaktadır. Birinci bölümde, uçak gemilerinin tarihçesi, tanımı, sınıflandırılması, yetenekleri ve maliyeti üzerinde durulmakta, dünyada söz konusu platformlara sahip ülkeler ile mevcut ve görünür gelecekteki filo yapısı hakkında değerlendirmeler yapılmaktadır. Türkiye'de uçak gemisi tedarik sürecine odaklanan ikinci bölümde, konunun ilk gündeme gelmesinden bugüne kadarki gelişimi masaya yatırılmaktadır. Üçüncü bölümde, Türk Deniz Kuvvetleri’nin harekât ihtiyaçları ve bu bağlamda tedariki planlanan amfibi hücum gemisinin rolü ele alınmaktadır. Dördüncü bölümde ise hizmete girdiğinde amfibi hücum gemisinin uçak gemisi ihtiyacını ne ölçüde karşılayacağı tartışılmakta, ayrıca gelecekte tedariki gündeme gelmesi muhtemel klasik uçak gemisi ve uygun uçak seçimi hususlarında önerilerde bulunulmaktadır.

\section{Uçak Gemilerine Genel Bir Bakış}

\section{Tarihçe}

Uçak gemisinin geçmişi 20. yüzyılın başlarına dayanmaktadır. 14 Kasım 1910, bir gemi üzerinden ilk uçağın kalktığı tarih olarak kayıtlara geçmiştir. Bir uçağın gemi üzerine ilk iniş tarihi ise 18 Ocak 1911'dir. Her iki denemeyi de gerçekleştiren Amerikan Donanması'dır. İlk denemede güvertesi piste dönüştürülen USS Birmingham kruvazörü, ikincisinde ise gerekli yakalama donanımları yerleştirilen USS Pennsylvania zırhlı kruvazörü kullanılmıştır (Fontenoy, 2006: 2). Söz konusu denemeler doğrudan uçak gemilerinin inşasına giden süreci başlatmamakla beraber bir uçağın gemi üzerinden iniş-kalkış yapabileceğini göstermesi bakımından önemlidir (Hendrix, 2015: 8). Diğer yandan iki denemede de gemilerin limanda demirli vaziyette olduğu görülmektedir. 
Nitekim seyir halindeki bir gemi üzerinden ilk uçuş 2 Mayıs 1912 'de İngiliz Kraliyet Donanması tarafından gerçekleştirecektir. Bu tarihi uçuşa ev sahipliği yapan platform HMS Hibernia isimli muharebe gemisidir (Fontenoy, 2006: 3).

Uçak gemilerinin ilk örnekleri Birinci Dünya Savaşı'nın hemen öncesinde ortaya çıkmıştır. Birinci Dünya Savaşı ise uçak-gemi işbirliğinin gerçek muharebe şartlarında ilk kez test edilmesini sağlamıştır. Burada Eylül 1914'teki Tsingtao Muharebesi üzerinde özellikle durmak gerekir. Zira Japon Donanması'na ait IJN Wakamiya uçak gemisinden kalkan uçakların Çin'in Tsingtao Limanı'ndaki Alman kuvvetlerini hedef aldığı muharebe, gemi konuşlu uçakların icra ettiği ilk başarılı hava taarruzu olarak tarihe geçmiştir (Global Security, 2011a). Savaşta kullanılanlar da dâhil olmak üzere başlangıçta uçak gemilerinin hizmetteki diğer savaş ya da ticaret gemilerinin gövdelerinin tadil edilmesiyle göreve alındığı görülmektedir. Ne var ki ilerleyen süreçte doğrudan bu amaca yönelik platformlar inşa edilmeye başlanmıştır. 1924'te İngiliz Kraliyet Donanması'nın kuvvet yapısına dâhil olan HMS Hermes, tasarım aşamasından itibaren uçak gemisi olarak hizmet vermesi planlanan ilk platformdur (Chen, t.y.).

İki savaş arası dönemde uçak gemilerinin gelişimi devam etmiştir. İkinci Dünya Savaşı başladığında ABD, İngiltere ve Japonya'nın hatırı sayılır bir uçak gemisi filosu vardır. Üstelik bu üç ülke savaş boyunca yenilerini de inşa etmiştir. Diğer yandan Fransa'nın bir adet uçak gemisi olsa da bu gemi hiçbir muharebeye katılmamış; Almanya ve İtalya'daki inşa çalışmaları ise tamamlanamamıştır (Sommerville, 2012: 86). İkinci Dünya Savaşı, uçak gemilerini deniz harekâtlarında öne çıkaran bir dizi muharebeye sahne olmuştur. Öyle ki İngiliz Kraliyet Donanması'nın Taranto ve Japon Donanması'nın Pearl Harbor baskınları uçak gemilerinin denizden karaya darbe harekâtlarında ne denli etkili olabileceklerini kanıtlamıştır. Amerikan ve Japon Donanmaları arasında gerçekleşen Mercan ve Midway deniz muharebeleri ise uçak-gemi işbirliğinin suüstü harbi (SUH) görevlerindeki tayin edici rolünü göstermiştir. Bu noktada Mercan Denizi Muharebesi'ne ayrı bir parantez açmak gerekir. Zira deniz harp tarihinde ilk kez bir muharebede savaş gemileri doğrudan birbirlerine angaje olmamış, çarpışmalar sadece tarafların hava unsurları arasında cereyan etmiştir (Hart, 2015: 478). 
20.yüzyılda dünyanın belli başlı donanmalarının kuvvet yapısındaki en önemli değişikliklerden biri muharebe gemisinin yerini uçak gemisine bırakmasıdır. Özellikle 1944-45 döneminde Pasifik harekât alanındaki gelişmelerin bu değişimde etkisi olmuştur (Till, 2004: 125). İkinci Dünya Savaşı ile beraber ana gemi (capital ship) konumunu alan uçak gemisi, izleyen dönemde açılı uçuş pisti ve buharlı mancılık gibi yeniliklerle gelişimini sürdürmüştür. Söz konusu gemiler başta Kore, Vietnam, Falkland ve Birinci ve İkinci Körfez savaşları olmak üzere birçok kriz bölgesinde boy göstermiştir. Tartışmasız şekilde ABD, modern uçak gemisi harekâtında öncü rol oynamaktadır. Ancak ABD hiçbir zaman bu alanda yalnız kalmamıştır. Özellikle İngiltere, güverteden dikey ya da kısa mesafeden kalkış yapabilen ve yine güverteye dikey iniş gerçekleştirebilen Sea Harrier FRS.I uçakları için tasarlanan ve küçük boyutları nedeniyle "cep uçak gemisi" olarak nitelendirilen yenilikçi çözümüyle farklı bir alternatif ortaya koymuş ve birçok ülke tarafindan örnek de alınmıştır.

\section{Tanım ve Sinıflandırma}

Uçak gemisi, kısaca uçakların iniş-kalkış yapabildiği savaş gemisi olarak tanımlanabilir. Ancak hemen belirtmek gerekir ki uçak gemisi bir savaş gemisi sınıfının genel adıdır. Dünya donanmalarında farklı tasarım özellikleri haiz uçak gemileri hizmet vermektedir. Boyut (hafif, süper vs.) ve tahrik sistemi (konvansiyonel ve nükleer) üzerinden de sinıflandırmalar yapılmakla birlikte bugün daha ziyade dikkate alınan iniş-kalkış konfigürasyonudur. $\mathrm{Bu}$ sınıflandırmaya göre uçak gemileri, Mancınık Destekli Kalkış Bariyerle Duruş (Catapult Assisted Take-Off Barrier Arrested Recovery/CATOBAR), Kisa Mesafeden Kalkış Bariyerle Duruş (Short Take-Off Barrier Arrested Recovery/STOBAR) ve Kısa Mesafeden Kalkış Dikey İniş (Short Take-Off Vertical Landing/STOVL) olmak üzere üçe ayrılmaktadır.

CATOBAR'da kalkış için mancınık sistemi kullanılmaktadır. Uçağın çok kısa bir mesafede kalkış süratine ulaşmasını sağlayan mancınık sistemi buhar gücüyle çalışmaktadır. İniş ise uçağın arkasında yer alan yakalama kancasının pist üzerindeki teli yakalamasıyla gerçekleşmektedir. CATOBAR'ın en önemli avantajı, farklı tipteki uçakların tam silah ve yakıt yükü ile harekât icra etmesini 
olanaklı kılması dolayısıyla operasyonel açıdan büyük esneklik sağlamasıdır. Dezavantajı ise tüm iniş-kalkış konfigürasyonları içerisinde en yetenekli olduğu kadar en maliyetli çözümü teşkil etmesidir (Li ve Weuve, 2010: 20). Bu bağlamda mancınık sistemlerinde elektronik ve mekanik parça sayısının fazlalığının ve bakım, idame ve işletme için çok sayıda personel ve zaman ayrılması gerektiğinin altını çizmek yerinde olacaktır (Kahlon, Gupta, Dahiya ve Chaturvedi, 2017: 61). Öte yandan yakın gelecekte buharlı mancınıkların yerini Elektromanyetik Uçak Firlatma Sistemi (Electromagnetic Aircraft Launch System/EMALS) teknolojisine bırakması öngörülmekte olup, uygulama Amerikan Donanması'nın Gerald R. Ford sınıfı yeni nesil uçak gemileriyle başlamıştır. Farklı platformlara entegre edilebilen EMALS'in buharlı mancınık sistemine göre düşük ömür devir maliyeti, daha az personelle işletilme, sorti sayısını arttırma, kızılötesi izi azaltma, küçük hacim ve ağırlık tasarrufu gibi avantajları olduğu belirtilmektedir (General Atomics, t.y.).

EMALS ve maliyet ilişkisi bağlamındaki en güncel tartışma İngiltere'nin Queen Elizabeth sınıfı yeni nesil uçak gemilerinin inşa sürecinde yaşanmıştır. Öyle ki başlangıçta STOVL olarak düşünülen tasarım EMALS'in gündeme gelmesiyle CATOBAR'a, ardından tekrar STOVL'a çevrilmiştir. Hükümet kanadı nihai kararın gerekçesini platform başına 500 milyon ile 1.8 milyar avro arasında tutacağı belirtilen ilave maliyet olarak göstermiştir. Buna mukabil aynı dönemde savunma uzmanlarının rakamın abartılı olduğu ve 400 milyon avroyu aşmayacağı yönünde tahminleri yayınlanmıştır (Harding, 2012). Kaldı ki aynı yayınlarda performans yönünden CATOBAR tipi F-35C'lerin gerisinde kalsa da STOVL tipi F-35B'lerin uçak başına en az 20 milyon dolar pahalı olduğu ve bakım-idame için de \%25 daha fazla harcama gerektirdiği dolayısıyla ömür devir maliyeti açısından bakıldığında aslında uzun vadede EMALS'in öne çıktığı yönünde iddialar da dile getirilmiştir. Bu bağlamda daha yetenekli bir platform ve uçak tipinin tercih edilmemesinde maliyetten ziyade ticari çıkarların ve istihdam kaygılarının etkili olduğu düşünülmektedir. Şöyle ki F-35B kendi sınıfında yegâne seçenektir. Ancak CATOBAR'ın seçilmesi durumunda F-35C'den başka alternatifler de gündeme gelebilecektir ki bunun İngiltere'nin, \%15'lik iş payına sahip olduğu ve 30 y1lı aşan bir süreçte 3.000 civarında uçağın üretiminin öngörüldüğü F-35 Programı'ndaki çıkarlarını riske sokmasından çekinilmiştir (Save The Royal Navy, 2012). 
Bir diğer konfigürasyon olan STOBAR'da uçak kendi itki gücüyle kalkış yapmaktadır. Geminin baş kısmında yer alan eğimli rampanın (ski jump) burada kalkışı kolaylaştırıcı işlevi vardır. Bu tip gemilerde iniş ise aynı CATOBAR'daki gibi yakalama kancasının pist üzerindeki teli yakalamasıyla gerçekleşmektedir. CATOBAR ile karşılaştırıldığında STOBAR konfigürasyonunda kalkış için hareketli hemen hiçbir parçanın olmamasından ötürü geliştirme ve idame maliyetleri düşmekte, personel ihtiyacı azalmaktadır. Ayrıca mancınık sistemi için gereken ilave gücü sağlayacak nükleer reaktör benzeri yüksek performanslı tahrik sistemi ihtiyacı da bulunmamaktadır. Diğer taraftan bu konfigürasyonun başlıca dezavantajı, kalkış için yüksek güç/ağırlık oranına ihtiyaç duyulması dolayısıyla uçakların tam görev yükü ile havalanamamasıdır (Kahlon vd., 2017: 59). Nitekim bu nedenle daha ziyade hava savunma veya kısa menzilli, ağır silah yükü gerektirmeyen yer hedeflerine taarruz görevlerine uygun oldukları değerlendirilmektedir (Erickson, Denmark ve Collins, 2012: 30).

STOVL'da ise uçak, aynı STOBAR'daki gibi kendi itki gücüyle ve genellikle eğimli rampa üzerinden kalkış yapmaktadır. Bu tipteki gemilerin farkı, inişin yakalama donanımı vasıtasıyla değil, dikey olarak gerçekleştirilmesidir. Gerçi teorik olarak STOVL tipi uçaklar dikey kalkış da yapabilir. Ancak silah yükü ve yakıt miktarının azalmasına yol açtığı için bu, pratikte pek tercih edilmemektedir. Diğer konfigürasyonlara göre daha küçük boyutlu platformların hizmete alınmasını olanaklı kılan STOVL'un en önemli avantajı, inşa ve idame masraflarının düşük olmasıdır. Dezavantajı ise STOVL tipi uçakların menzillerinin nispeten kısa olması ve bunun özellikle taarruz görevlerindeki etkinliği azaltmasıdır (Li ve Weuve, 2010: 20). Bu noktada F-35'in muharebe yarıçapının STOVL versiyonunda (F-35B) $833 \mathrm{~km}$, CATOBAR versiyonunda (F-35C) ise $1.111 \mathrm{~km}$ olduğu bilgisi, aradaki farkın anlaşılmasını sağlayacaktır (Global Security, t.y.). Yine bu tip uçakların geliştirme ve bakım-idame maliyetlerinin fazlalığını da dezavantajları arasında saymak gerekir.

Öte yandan esasen amfibi hücum gemisi sınıfinda yer almakla beraber STOVL tipi uçakların harekâtına uygun başka gemiler de inşa edilmiştir. Tasarım özelliklerine göre Havuzlu Helikopter Gemisi (Landing Helicopter Dock/LHD), Helikopter Hücum Gemisi (Landing Helicopter Assault/LHA) veya Helikopter Taşıma Gemisi (Landing Platform Helicopter/LPH) olarak sinıflandırılan bu 
platformların uçak gemisi başlığı altında ele alınması tartışmalıdır. Bu gemilerin öncelikli görevi taşıdıkları helikopter ve çıkarma araçları ile amfibi harekâtların icrasıdır. Ancak STOVL tipi uçakların konuşlanmasına uygun güverte yapıları ve teknik donanımları gerektiğinde uçak gemilerinin görevlerini de icra etmelerini mümkün kılmaktadır.

\section{Yetenekler ve Maliyet}

Günümüzde uçak gemileri nükleer denizaltılarla birlikte küresel ölçekte harekât icra etme yeteneğine sahip bir donanma, denizcilik terimiyle bir Mavi-Su Donanması (Blue-Water Navy) olmanın gerek şartları arasındadır. Açık denizlerin serbestîsi ilkesi uyarınca karasularının dışındaki tüm alanlarda herhangi bir kısıtlamaya tabi olmaksızın varlık gösterebilen uçak gemileri, bölgesel ve küresel ölçekte güç aktarımı (power projection) yeteneği kazandırmaktadır. Karadaki hava üslerine bağımlılı̆̆ ortadan kaldıran uçak gemilerinin konuşlanma ve harekât icra etmek için bir ülkeden izin almaya gerek bırakmaması büyük avantajdır. Uçak gemileri sayesinde karadaki uçakların menzili dışında kalan dost unsurlara hava şemsiyesi sağlanması mümkün hale gelmektedir. Sabit üslerin aksine bu platformların hareketli olması ise hasım tarafindan tespit ve imha edilmelerini zorlaştırmaktadır. Üstelik yeri tam olarak tespit edilemeyen bir platforma sahip olmak baskın tarzında bir taarruza uğrama ihtimalini de azaltmaktadır. Uçak gemilerinin çok uluslu harekâtların karar alma süreçlerindeki etkinliği arttırma, dış politikayı destekleme ve bayrak ülkesine saygınlık kazandırma gibi işlevlere de sahip olduğunu eklemek gerekir.

Diğer yandan sıralanan tüm avantajlarına karşın uçak gemilerinin sınırlı sayıda ülke tarafından tercih edilmesi dikkat çekicidir. Muhakkak ki nedenler arasında harekât ihtiyaçlarının bu tip bir platformu gerektirmemesi vardır. Ayrıca tüm büyük suüstü gemileri gibi yüksek maliyetleri, hava ve denizaltı tehdidine karşı savunmasız olmaları (Till, 2004: 125) ve hasım için öncelikli hedef listesinde yer almalarından ötürü muhtemel bir hasar ya da kayıp durumunda moral çöküntüsü yaratabilme potansiyelleri de göz ardı edilmemelidir (Topuz, 2016: 146). Bu noktada sıklıkla gündeme gelmesi nedeniyle maliyet faktörüne ayrı bir parantez açmak yerinde olacaktır. Uçak gemilerinin ilk alım ve bakım-idame 
masraflarının bir hayli yüksek olduğu doğrudur. Üstelik hesaba hava araçları ve uçak gemisini korumakla görevli suüstü ve sualtı platformları için ayrılması gereken kaynak da eklendiğinde maliyet faktörü daha da öne çıkmaktadır. Örneğin Amerikan Donanması'nın USS Gerald R. Ford uçak gemisinin inşa maliyeti 13.5 milyar dolardır ki (New Wars, t.y.) buna refakatle görevli diğer savaş gemilerinin ve hava araçlarının maliyeti dâhil değildir. Dahası uçak gemisi, refakat gemileri, hava araçları ve 6.700'e yakın personelden müteşekkil bir görev grubunun günlük operasyon maliyeti neredeyse 6.5 milyon doları bulmaktadır (Hendrix, 2013: 5). Gerçi Amerikan Donanması dışındaki örneklerde rakamlar düşmektedir. Örneğin Fransız Donanması'nın FS Charles De Gaulle uçak gemisinin inşa maliyeti 3.7 milyar dolar, İtalyan Donanması'nın ITS Cavour uçak gemisinin ise 2 milyar dolardır (New Wars, t.y.). Fakat rakamların nispeten az olması çekirdeğinde uçak gemisinin yer aldığ 1 bir açık deniz görev grubunu oluşturup idame etmenin belli bir iktisadi güç gerektirdiği gerçeğini değiştirmemektedir. Kaldı ki bir ülke uçak gemisini ihtiyaç olarak belirlese de ihtiyacın ne zaman ortaya çıkacağını bilemeyeceği için sürekli bir platformu faal durumda tutması gerekecektir. Dolayısıyla uçak gemisi tedarikinde maliyet hesapları en az iki platform üzerinden yapılmalidir (Topuz, 2016: 146).

\section{Mevcut ve Gelecekteki Filo Durumu}

2018 yılı başı itibariyle dünyada STOVL kabiliyetli uçakların harekâtına uygun amfibi hücum gemileri de dâhil olmak üzere donanmasında uçak gemisi bulunan ülke sayısı 12'dir. Toplamda 37 uçak gemisinin bulunduğu listede ABD 20, Japonya 4, İngiltere, İtalya ve Avustralya 2'şer, Fransa, Rusya, Çin, Hindistan, İspanya, Tayland ve Güney Kore ise 1'er platform ile yer almaktadır.

Kuşkusuz uçak gemileri denildiğinde akla ilk gelen ülke ABD'dir. Amerikan Donanması'nın kuvvet yapısında CATOBAR tipi 11 uçak gemisi ile STOVL uçaklarının harekâtına uygun 9 amfibi hücum gemisi bulunmaktadır. Uçak gemilerinin 10'u Nimitz, 1'i Gerald R. Ford sınıfıdır. İlki 1975 yılında hizmete giren Nimitz'lerin boyu 332,8 metre, tam yüklü deplasman1 97.000 tondur. $\mathrm{Bu}$ sınıftaki gemilerin yerini alması öngörülen ve ilki 2017 yılında donanmaya teslim edilen Gerald R. Ford'ların ise boyu 332,8 metre, tam yüklü deplasmanı 100.000 
tondur. Nimitz'ler 60+, Gerald R. Ford'lar ise 75+ uçak taşıma kapasitesine sahiptir. Amerikan Donanması, Gerald R. Ford sınıfı en az iki geminin daha tedarikini planlamaktadır (United States Navy, 2017). Amfibi hücum gemisi sınıfinda yer alan platformların ise 8'i Wasp, 1'i America sınıfidır. LHD sinıfinda yer alan ve ilki 1989 yılında hizmete giren Wasp'ların boyu 253,2 metre, tam yüklü deplasmanı 40.650 tondur. LHA sinıfinda yer alan ve ilki 2016 yılında donanmaya teslim edilen America'ların ise boyu 260,7 metre, tam yüklü deplasmanı 43.745 tondur. Amerikan Donanması, America sınıfi ilave gemilerin hizmete alınmasını öngörmektedir (United States Navy, 2018). Bu noktada bir parantez açarak Amerikan Donanması'nın amfibi hücum gemilerini uçak gemileri arasında saymadığının altını çizmek gerekir. Uzmanlara göre bu olası bütçe kesintilerini aşmak için yapılan bir isimlendirme oyunudur. Zira aksi durumda uçak gemisi sayıs1 gereğinden fazla görünecek, bu da eleştirileri beraberinde getirecektir (Farley, 2014).

Soğuk Savaş döneminin harekât ihtiyaçları doğrultusunda tasarlanan Invincible sınıfı uçak gemilerini hizmet dışına çıkaran İngiltere, Queen Elizabeth sinıfi 2 yeni gemi tedarik etmektedir. Sinıfa ismini de veren HMS Queen Elizabeth 2017 yilında donanmaya teslim edilmiştir (Allison, 2017). İkinci gemi HMS Prince of Wales ise denize indirilmiş olup, 2019 yılında donanmaya teslimi planlanmaktadır (Millar, 2017). STOVL konfigürasyonundaki bu gemilerin boyu 284 metre, tam yüklü deplasmanı 70.600 tondur. Gemiler 40 sabit ve döner kanatlı hava aracı taşıma kapasitesine sahiptir (Atalan, 2015: 46). Öte yandan FA2 Sea Harrier'ları hizmet dışına çıkaran İngiliz Kraliyet Donanması'nın envanterinde halen STOVL kabiliyetli uçak bulunmamaktadır. Boşluğu dolduracak F35BLightining-II'lerle eğitimlere 2018 yılında başlanılması ve 2023 yılında tam harekât kabiliyeti kazanılması hedeflenmektedir (Allison, 2017).

Fransa, CATOBAR tipi FS Charles De Gaulle isimli tek uçak gemisini 2001 yılında hizmete almıştır. Boyu 261,5 metre, tam yüklü deplasmanı 42.000 ton olan gemi 40 adet sabit ve döner kanatlı hava aracı taşıyabilmektedir (Atalan, 2015: 42-43). Hâlen dünyada ABD dışında CATOBAR tipi uçak gemisi idame eden tek ülke Fransa'dır. Aslında Fransa, operasyonel ihtiyaçları dikkate alarak gemi sayısını ikiye çıkarmayı planlamıştır. Ancak bütçe sorunları nedeniyle projede somut bir ilerleme kaydedilememiştir (Defence Industry Daily, 2014). Öte 
yandan Fransız Donanması'nın kuvvet yapısında 3 Mistral sinıfi LHD de bulunmaktadır. Misır Donanması tarafından da hizmete alınan bu gemilerinSTOVL tipi uçakların harekâtına uygun olmadığı ifade edilmektedir (Defence Industry Daily, 2016).

ABD benzeri açık deniz görev grupları oluşturmayı hedefleyen Sovyetler Birliği, STOBAR tipi 2 uçak gemisi inşa etmeyi planlamıştır. Birinin inşası yarım kalmış olsa da bu tip gemilerin ilki olan Kuznetsov, 1991 y1lında hizmete alınmıştır. Sovyetler Birliği'nin dağılması sonrasında Rusya tarafından devralınan ve bugün Rus Donanması'nın tek uçak gemisi olan Kuznetsov'un boyu 304,5 metre, tam yüklü deplasman1 58.600 tondur. Gemide 30 sabit ve döner kanatlı hava aracı taşınabilmektedir (Atalan, 2015: 50-51). Henüz kesinleşmemekle beraber Rusya, yeni bir uçak gemisinin tedariki hususunda çalışmalar yapmaktadır. Boyutları itibariyle Amerikan Donanması'ndaki Nimitz sınıfına eş değer olacağı ifade edilen geminin 2030 yılında hizmete girmesi öngörülmektedir (Pleasance, 2017).

Çin, Kuznetsov uçak gemisinin kardeş platformu olan ancak inşası tamamlanamadığı için kızakta kalan Varyag'1 2000 yılında Rusya'dan satın almıştır. Beklendiği gibi inşa çalışmalarını tamamlayan Çin, gemiyi CNS Liaoning adıyla 2012 yılında hizmete sokmuştur. STOBAR konfigürasyonundaki CNS Liaoning'in tasarım yönünden Kuznetsov'tan büyük bir farkı yoktur. Bununla birlikte silah ve sensör sistemleri açısından bazı değişiklikleri ihtiva ettiği görülmektedir (Atalan, 2015: 50-51). Önümüzdeki dönemde ana vatandan uzak bölgelerdeki donanma varlığını arttırmayı hedefleyen Çin, uçak gemisi filosunun geliştirilmesine büyük önem vermektedir. Bu çerçevede CNS Lioaning ile benzer özellikler taşıyan ve Çin'de inşa edilen ilk uçak gemisi unvanını alan ikinci platformun 2019 yılında seyir denemelerine başlanması beklenmektedir. Bunun yanında özgün tasarıma sahip olacağı söylenen üçüncü platform üzerinde de çalışmalar sürmektedir. $\mathrm{Bu}$ geminin diğerlerinden farklı olarak CATOBAR konfigürasyonunda inşa edileceği belirtilmektedir. Uzmanlara göre Çin, egemenlik iddiaları ve denizaşırı çıkarlarını koruyabilmek için en az 5-6 uçak gemisine ihtiyaç duymaktadır (Seidel, 2017).

2017 yılında INS Viraat'1 hizmet dişına çıkaran Hindistan, halen INSVikramaditya isimli bir uçak gemisini idame etmektedir (Rao, 2017). Aslında 
bu gemi ilk kez 1990 y1lında Admiral Gorshkov uçak gemisi olarak Sovyet Donanması'nda hizmete girmiştir. STOVL konfigüsyonunda olan ve Sovyetler Birliği'nin dağılması sonrasında bir süre Rus Donanması bünyesinde görev yapan gemi 1996 yılında hizmet dışına çıkarılmış, akabinde ise Hindistan tarafından satın alınmıştır. Hindistan'ın geniş kapsamlı bir tadilat ile STOBAR harekâtına uygun hale getirdiği gemi, 2013 yılında Hint Donanması'na katılmıştır. Boyu 284 metre, deplasman1 44.500 ton olan INS Vikramaditya, 30'dan fazla sabit ve döner kanatlı hava aracı taşıyabilmektedir (Indian Navy, t.y.). Hâlihazırda Hindistan, ilk yerli uçak gemisi olan INS Vikrant'ın inşa çalışmalarını tamamlamak üzeredir. Tasarım çalışmaları devam eden INS Vishal isimli üçüncü uçak gemisinin ise en erken 2025 yılında hizmete gireceği belirtilmektedir (Rao, 2017). CATOBAR konfigürasyonunda olacağı belirtilen INS Vishal'in EMALS ile donatılması beklenmektedir (Indian Patriot News, 2018).

Bir Akdeniz ülkesi olan İtalya, uçak gemilerinin sadece okyanusa kıyısı bulunan ülkeler tarafından tercih edildiği varsayımını çürütmektedir. İtalyan Donanması'nın kuvvet yapısında STOVL tipi 2 uçak gemisi bulunmaktadır. ITS Garibaldi isimli ilk gemi 1985 yllında hizmete girmiştir. Boyu 180 metre, tam yüklü deplasmanı 13.850 ton olan gemi 16 sabit ve döner kanatlı hava aracı taşıyabilmektedir. ITS Cavour isimli ikinci geminin hizmete giriş yılı ise 2007'dir. Boyu 235,6 metre, tam yüklü deplasmanı 27.100 ton olan gemi, 24 sabit ve döner kanatlı hava aracı taşıma kapasitesine sahiptir (Atalan, 2015: 48-49). Diğer yandan güç aktarımı yeteneğini arttırmak isteyen İtalyan Donanması, LHD sınıfı yeni bir geminin tedarikini projelendirmiştir. İlk sac kesim töreni Temmuz 2017'de yapılan bu geminin de STOVL uçaklarının harekâtına uygun olacağı belirtilmektedir (Peruzzi, 2017).

Deniz kontrol gemisi (sea control ship) konseptinin en iyi örneği olarak kabul edilen SNS Principe de Asturias'1 hizmet dışına çıkaran İspanya, onun yerini yine STOVL tipi uçakların harekâtına imkân tanıyan SNS Juan Carlos I isimli LHD ile doldurmuştur. İspanyol Donanması'nın uçak gemisi rolünü de üstlenebilecek çok maksatlı bir platform ihtiyacına yönelik tasarlanan SNS Juan Carlos I 2010 yılında hizmete girmiştir. Geminin boyu 231 metre, deplasmanı 26.000 tondur. Uçak gemisi rolünde gemide 10-12 uçak ile aynı sayıda helikopter 
taşınabilmektedir (Armada Espanola, t.y.). İleriki bölümlerde bahsedileceği üzere bu geminin bir benzeri Türk Donanması tarafından tedarik edilmektedir.

İkinci Dünya Savaşı sonrasında uçak gemisi idame etmesi yasaklanan Japonya, 2 Hyuga ve 2 Izumo sinıfi LPH ile listede yer almaktadır. Her ne kadar Japon Donanması tarafindan helikopter muhribi olarak sinıflandırılsalar da gemilerin görüntü ve tasarım özellikleri LPH'ler ile örtüşmektedir. İlki 2009 yılında hizmete giren Hyugo'ların boyu 197 metre, tam yüklü deplasmanı 19.000 tondur. Sınıfın ilk gemisinin 2015 yılında donanmaya katıldığı Izumo'ların ise boyu 248 metre, tam yüklü deplasman1 24.000 tondur. Mevcut halleriyle Hyuga ve Izumo sınıfı LPH'ler STOVL uçaklarının iniş-kalkış yapmasına uygun değildir. Fakat küçük modifikasyonlarla sorunun çözülebileceği düşünülmektedir (Atalan, 2015: 125-126). Bugün için Japon Donanması'nın envanterinde STOVL kabiliyetli uçak bulunmamaktadır. Ancak Aralık 2017'de hükümet kaynaklarına dayandırılarak çıan haberlerde Japonya'nın Izumo'ları uçak gemisine dönüştürme yönünde hazırlık yaptığı ve F-35B tedarikinin gündemde olduğu iddia edilmiştir (Kubo ve Kelly, 2017).

Güney Kore, ROKS Dokdo isimli bir LHD'ye sahiptir. 2007 y1linda hizmete giren geminin boyu 199 metre, tam yüklü deplasmanı 18.860 tondur. Hâlihazırda Güney Kore Donanması'nın envanterinde STOVL kabiliyetli uçak bulunmamaktadır. Ancak geminin eğimli rampa eklenmesiyle bu tip uçakların inişkalkış yapmasına uygun hale getirilebileceği ifade edilmektedir. Güney Kore, Nisan 2017'de Dokdo sınıfı ikinci LHD'nin inşasına başlamış olup, geminin 2020 yılında hizmete girmesi planlanmaktadır (Defence Industry Daily, 2017).

Tayland için uçak gemisi ile bölgesel/küresel güç statüsü arasındaki ilişkiyi muğlâklaştıran ülke yorumu yapılabilir. Tayland Kraliyet Donanması, 1997 y1lından beri STOVL tipi HTMS Chakri Naruebet isimli uçak gemisini hizmette tutmaktadır. Boyu 182,6 metre, tam yüklü deplasmanı 11.485 ton olan gemi, 12 sabit ve döner kanatlı hava aracı taşıma kapasitesine sahiptir (Atalan, 2015: 48).

Uçak gemisi harekâtlarında geçmişten gelen bir tecrübeye sahip olan Avustralya, bugün 2 Canberra Sinıfi LHD ile listede yer almaktadır. Bu gemilerden ilki olan HMAS Canberra 2014 yılında, kardeş platform HMAS Adelaide ise 2015 yllında hizmete girmiştir (Royal Australian Navy, t.y.). Canberra'lar İspanya'nın SNS Juan Carlos ILHD'si temel alınarak inşa 
edilmişlerdir. Dolayısıyla bazı modifikasyonlar yapılmış olsa da tasarım açısından benzerlik gösterdikleri söylenebilir. Halen Avustralya Kraliyet Donanması'nın envanterinde STOVL kabiliyetli uçak bulunmamaktadır. Ancak gemilerin baş kısmındaki eğimli rampanın kaldırılmamış olması gelecekte F-35B savaş uçaklarının tedarik edilebileceği şeklinde yorumlanmaktadır (Atalan, 2015: 274).

Günümüzde bazı uzmanlar teknolojideki gelişmeleri özelikle de artan füze tehdidini gerekçe göstererek uçak gemilerinin yakında "modasının geçeceğini" savunmaktadirlar (Friedman ve Friedman, 2015: 494). Hatta bu konuyu ele alan raporlar dahi yayınlanmıştır (Cohen, 2015). Kuşkusuz uçak gemilerinin geleceğine yönelik bazı soru işaretlerinin olduğu aşikârdır. Mamafih en azından görünür gelecekte uçak gemilerinin mevcudiyetini koruyacağı anlaşılmaktadır. Zira yukarıda da özetlendiği üzere halen kuvvet yapısında uçak gemisi bulunan ülkeler değil filolarını lağvetmek, aksine modernize etmektedir. Ayrıca geçmişte hiç uçak gemisi idame etmemiş ülkelerden dahi bugün tedarik projesi yürütenler vardır ki bunlar arasında Türkiye de bulunmaktadır.

\section{Deniz Kontrol Gemisinden Havuzlu Helikopter Gemisine}

Türk Deniz Kuvvetleri bünyesinde uçak gemisi tedarikine yönelik çalışmalar 1990'lı yılların ikinci yarısında başlamıştır. Bu tip bir geminin kuvvet yapısına dâhil edilmesi düşüncesinin ortaya çıkmasında Balkanlar'da yaşanan gelişmeler etkili olmuştur. Öyle ki Bosna Savaşı'nda NATO müdahale edinceye kadar Sırbistan'ın saldırılarının durdurulması mümkün olmamış, Arnavutluk'taki Türk vatandaşlarının tahliyesinde ise ciddi zorluklarla karşılaşılmıştır (Gürdeniz, 2017). O dönem yapılan değerlendirmelerde kuvvet yapısına dâhil edilecek uçak gemisinin gerek caydırıcılık gerekse savaş dışı harekâtlar açısından büyük getirileri olacağı sonucuna varılmıştır. Nitekim bizzat Deniz Kuvvetleri Komutanı Oramiral Salim Dervişoğlu tarafından İspanya, İtalya ve Tayland gibi ülkelerin sahip olduğu tipte 12.000-16.000 tonluk bir hafif uçak gemisinin tedariki üzerinde durulduğu açıklanmıştır (Mönch TR, 1998: 40).

1997 yılında Türk Deniz Kuvvetleri tarafindan hazırlanan “Açık Denizlere Doğru" başlıklı strateji belgesinde, gelecekte kuvvet yapısında yer alabilecek muhtemel ana muharip unsurlar arasında bir adet hafif uçak gemisi de sayılmıştır. 
Burada ilginç olan nokta hafif uçak gemisinin deniz kontrol gemisi olarak tanımlanmasıdır (Türk Deniz Kuvvetleri, 1997: 26). Aslında deniz kontrol gemisi 1960'lı yılların sonlarında Amerikan Donanması için gündeme gelen ve ana görevi deniz ulaştırma yollarının güvenliğini sağlamak olan düşük maliyetli hafif uçak gemisi tasarımının adıdır (Global Security, 2011b). Türk Deniz Kuvvetleri'nin deniz kontrol gemisi tanımını kullanması kuvvet nezdinde bazı kaygılar olduğuna işaret etmektedir ki Gürdeniz'in (2017) tedariki engellemek isteyecek iç ve dış baskı gruplarına karşı böyle bir yola gidildiği yönündeki değerlendirmesi dikkat çekicidir.

Her ne kadar uçak gemisi hedefi en yetkili ağızlar tarafından ifade edilmiş hatta resmi belgelere bile girmiş olsa da ilerleyen süreçte tedarik planlamasında önceliğin amfibi hücum gemisine verildiği anlaşılmaktadır. Burada öncelik ifadesi özellikle kullanılmıştır. Zira 1997 yılında yayınlanan strateji belgesinde amfibi hücum gemisi, uçak gemisinden ayrı bir başlık altında ele alınmıştır (Türk Deniz Kuvvetleri, 1997: 26). Şüphesiz tedarik planlaması yapılırken daha ziyade askeri mülahazalar göz önünde bulundurulmuştur. Bununla beraber 17 Ağustos 1999 Marmara Depremi sonrasında yardım amaciyla Türkiye'ye gelen amfibi hücum gemilerinin insani ve doğal afetlerde oynadıkları müspet rolün görülmesinin de tedarik planlamasını etkilediği düşünülmektedir.

Başlangıçta amfibi hücum gemisi projesi kapsamında Havuzlu Çıkarma Gemisi (Landing Platform Dock/LPD) sinıfinda bir platformun tedariki öngörülmüştür. Ana tasarım amacı deniz piyade birliğinin havuz kısmındaki çıkarma araçlarıyla karaya çıkarılması olan LPD'ler sınırlı sayıda helikopter ya da tilt-rotorlu hava aracı taşıma imkânı sunmaktadır. Ne var ki dünyadaki örnekler ve edinilen tecrübeler ışığında harekât ihtiyaçlarının yeniden tanımlamasına koşut olarak platformun taşıması istenilen hava aracı sayısı ve tipi değişmiş, gelinen noktada proje STOVL uçaklarının iniş-kalkış yapabileceği LHD sınıfı bir amfibi hücum gemisinin tedarik çalışmasına dönüşmüştür. Böylece tek bir proje altında farklı iki ihtiyacın karşılanması hedeflenmiştir. Diğer yandan bu girişimin ara bir çözüm olarak görüldüğü, gelecekte ayrı bir uçak gemisi projesinin gündeme gelebileceğine yönelik işaretler bulunduğunu eklemek gerekir. $\mathrm{Bu}$ tespitin yapılmasında ana etken, bahriye kökenli denizcilerin ve siyasi karar vericilerin açıklamalarıdır. Örneğin 1997 tarihli strateji belgesinin hazırlanmasında önemli 
katkıları olan Emekli Koramiral Sağdıç'ın (Gürdeniz, 2013: 212-213), 2017 yılında düzenlenen bir çalıştayda Türk Deniz Kuvvetleri'nin gelecekteki kuvvet yapısında 2 adet LHD dışında 2 adet de deniz kontrol gemisinin yer alabileceğini belirtmesi (Sağdıç, 2017: 85) uçak gemisinin gündemden düşmediğini düşündürmektedir. Aynı şekilde amfibi hücum gemisinin inşasına başlanmış olmasına rağmen, Cumhurbaşkanı Erdoğan'ın "uçak gemimizi de yapacağıZ" (Hürriyet 2017) yönündeki açıklaması gelecekte ayrı bir projenin gündeme gelebileceğini göstermektedir.

Yukarıdaki değerlendirmelerin ardından amfibi hücum gemisi tedarik süreci daha ayrıntılı biçimde ele alınacak olursa bu alandaki ilk somut girişim, Haziran 2000'de Savunma Sanayii Müsteşarlığı (SSM) tarafından yayınlanan Bilgi İstek Dokümanı (BID) ile gerçekleşmiştir. BID'de 2006 yılında hizmete girmesi öngörülen LPD sınıfı amfibi hücum gemisinin görev ve teknik özellikleri açıklanmıştır. Belirtilen isterlerden Türk Deniz Kuvvetleri'nin deniz piyade taburu büyüklüğündeki bir kuvveti gerekli muharebe ve lojistik unsurlarıyla beraber ana üs desteği olmadan kriz bölgesine intikal ettirebilecek bir platforma sahip olmayı hedeflediği ortaya çıkmıştır. Burada özellikle üzerinde durulması gereken nokta istenilen hava aracı kapasitesidir. Platformun 15 tonluk iki genel maksat helikopterinin aynı anda iniş-kalkış yapabildiği uçuş güvertesine ve dört helikopter kapasiteli bir hangara sahip olmasının istendiği görülmüştür ki belirtilen yetenekler deplasmanı yaklaşık 13.000 ton olacak bir LPD'nin hizmete alınacağını göstermiştir (Mönch TR, 2000: 91). Öte yandan bu ilk girişim ihale aşamasına varmamış ve proje yeniden ele alınmak üzere iptal edilmiştir.

Amfibi hücum gemisi tedarikine yönelik ikinci girişim, 22 Haziran 2005 tarih ve 273 sayılı Savunma Sanayii İcra Komitesi (SSİK) kararıyla başlatılan ve 6 Nisan 2007'de BID'i yayınlanan LPD Projesi ile gerçekleşmiştir (Sünnetçi, 2016: 90). Aslına bakılırsa ilk etapta projenin bazı değişiklikler olmakla beraber ana hatlarıyla bir önceki girişimde tanımı yapılan benzer özelikleri haiz bir LPD’nin tedarikini öngöreceği yönünde genel bir kanaat vardır. Ne var ki 23 Şubat 2010'da yayınlanan Teklife Çağrı Dosyası (TÇD)'nda kullanıcının taleplerinin büyük ölçüde değiştiği ortaya çıkmıştır. Değiş̧ikliklerin en dikkat çekici olanı ise hiç şüphesiz hava aracı kapasitesindedir. TÇD'de 15 tonluk dört helikopterin inişkalkış yapmasına imkân tanıyan spotlardan bahsedilmiştir. Bu durum uçuş 
güvertesinin klasik LPD tasarımlarındakinin aksine kıç tarafında değil, ada kısmının yanal yerleştirilip üst güvertenin pist haline getirilmesi şeklinde olacağını göstermiştir. Yanal ada, genellikle LHD, LHA ve LPH sınıfı platformlarda kullanılan bir tasarım özelliğidir. Dolayısıyla projenin ismi resmen LPD olsa da gerek deplasmanı gerekse yetenekleri itibariyle tedarik edilecek platformun aslında LHD sınıfi bir amfibi hücum gemisi olacağı anlaşılmıştır (Mönch TR, 2010: 34 $35)$.

Uzun bir değerlendirme sürecinin sonunda 26 Aralık 2013 tarihli SSIK kararıyla LPD Projesi'nde kazanan İstanbul Tuzla'da yerleşik Sedef Gemi İnşaatı A.Ş. (Sedef Tersanesi) olmuştur. IDEF'15 Fuarı sırasında SSM ile Sedef Tersanesi arasında ön sözleşme imzalanmış, 1 Haziran 2015 'te imzalanan ve 15 Eylül 2015 'te yürürlüğe giren ana sözleşme ile de proje resmen başlamıştır. Tasarım değişiklikleri dikkate alınarak Çok Maksatlı Amfibi Hücum Gemisi Projesi (MultiPurpose Amphibious Assault Ship Project) adı altında imzalanan sözleşme, ana platform dışında 4 LCM-1E tipi Mekanize Çıkarma Aracı (Landing Craft Mechanized/LCM), 2 Araç ve Personel Çıkarma Aracı (Landing Craft Vehicle Personnel/LCVP), 2 Sert Karinalı Şişirilebilir Bot (Rigid Hull Inflatable Boat/RHIB) ve 1 rehberleme maksatlı Komutan Botu tedarikini kapsamaktadır. Proje kapsamında hizmete alınması planlanan LHD sınıfı platforma TCG Anadolu (L-400) isminin verilmesi kararlaştırılmış olup, geminin inşasına 30 Nisan 2016 itibariyle başlanmıştır. Sözleşmede belirtilen takvime göre geminin Ocak 2019'da suya indirilmesi, Nisan 2021'de ise geçici tesliminin gerçekleştirilmesi öngörülmektedir (Sünnetçi, 2016: 90).

TCG Anadolu, İspanyol Donanması'ndaki Juan Carlos-I ve Avustralya Kraliyet Donanması'ndaki Canberra sınıfı gibi İspanya'da yerleşik Navantia Tersanesi'nin ATHLAS 26.000 tasarımı üzerinden şekillendirilmiştir. Gemi, havuz bölümündeki modifikasyon dışında kardeş platformlar ile aynı gövde yapısına sahiptir. Ancak tahrik, silah ve sensör sistemlerinde önemli farkliliklara gidilmektedir (Sünnetçi, 2015: 148). Boyu 231 metre, tam yüklü deplasmanı 27.436 ton olacak TCG Anadolu, deniz piyade taburu büyüklügündeki bir kuvvetin tüm silah, araç ve gereçleriyle birlikte çevre denizlerdeki ve gerektiğinde Hint ve Atlas okyanuslarındaki harekât alanlarına ana üs desteği olmaksızın intikalini gerçekleştirebilecek ve taşıdığı çıkarma ve hava araçlarıyla amfibi operasyonlar 
icra edebilecektir (Savunma Sanayii Müsteşarlığı, 2017). Sıralanan yeteneklerinin yanı sıra STOVL uçaklarının harekâtına imkân tanıyan uçuş güvertesi ve elektronik/donanım altyapısına sahip olacaktır ki bu uçak gemisi rolünde de kullanılabileceği anlamına gelmektedir. İnşa Başlangıç Töreni sırasında TCG Anadolu'nun hava arac1 kapasitesi 12 F-35B veya 30 genel maksat helikopteri olarak verilmiştir (Sünnetçi, 2016: 91). Bununla beraber uçak gemisi rolünde daha fazla sayıda uçağın konuşlandırılması beklenebilir. Hâlihazırda Türk Deniz Kuvvetleri'nin envanterinde STOVL tipi uçak bulunmamaktadır. Ancak Türkiye'nin F-35B'lere ilgi duyduğu ve sayısı belli olmamakla beraber söz konusu uçakların tedariki hususunda ABD nezdinde girişimlerde bulunduğu iddiası geçtiğimiz dönemde basında yer almıştır (Herschelman, 2017a). Türk Deniz Kuvvetleri'nin gelecekte bu sinıfta ikinci bir platformu hizmete almayı planladığ 1 belirtilmektedir (Sünnetçi, 2015: 148-149). İkinci platformunun isminin TCG Trakya olması beklenmektedir (C4 Defence, 2018).

\section{Türk Deniz Kuvvetleri’nin Harekât İhtiyaçları ve LHD}

TSK'yı oluşturan üç kuvvetten biri olanTürk Deniz Kuvvetleri, menajman kontrolü ve yapısını esas alarak stratejik, operatif ve taktik seviyede teşkilatlanmıştır. Bu çerçevede karargâhı Ankara'da konuşlu Dz.K.K.lığı stratejik seviyede kuvvetin sevk ve idaresini gerçekleştirirken; ana ast komutanlıklar durumundaki Donanma Komutanlığı, Kuzey Deniz Saha Komutanlı̆̆ (Kz.Dz.Sh.K.1lğı), Güney Deniz Saha Komutanlığı (Gn.Dz.Sh.K.lığı) ve Deniz Eğitim ve Öğretim Komutanlığı (Dz.Eğt. ve Öğg.K.lığı) operatif seviyede; bunların bağlısı filo, görev grubu, gemi, boğaz, bölge ve üs komutanlıkları ise taktik seviyede deniz harekâtlarını icra etmektedir. Türk Deniz Kuvvetleri’nin ana deniz üsleri Gölcük, Erdek, Foça ve Aksaz'dadır. Ayrıca Trabzon, Bartın, Karadeniz Ereğlisi, İstanbul, Çanakkale, İzmir, Antalya, Mersin ve İskenderun'da deniz üsleri; Kartepe, Çanakkale ve Dalaman'da ise deniz hava üsleri mevcuttur (Akçadağ, 2015: 12-13). Mayıs 2018 itibariyle Türk Deniz Kuvvetleri'nin envanterinde suüstü, sualtı ve uçar unsurlar olarak 12 denizaltı, 16 firkateyn, 8 korvet, 19 hücumbot, 16 karakol botu, 11 mayın avlama gemisi, 32 çıkarma gemisi ve aracı, 33 yardımcı sınıf gemi, 14 uçak ve 35 helikopter yer almaktadır (Türk 
Deniz Kuvvetleri, t.y.). Kıyı birlikleri olarak ise Amfibi Deniz Piyade Tugayı, Sualtı Taarruz (SAT), Sualtı Savunma (SAS), Kurtarma ve Derin Dalış Sistemleri görev birimleri ile muhtelif muharebe destek birlikleri bulunmaktadır (Türk Deniz Kuvvetleri, 2015: 26). Uluslararası Stratejik Çalışmalar Enstitüsü'nün 2017 y1lı verilerine göre Türk Deniz Kuvvetleri'nin personel mevcudu 45.600'dür (IISS, 2017: 166).

Dünya donanmalarının sınıflandırılmasında farklı modeller geliştirilmiş olup, en yaygın kullanılanlardan biri İngiliz stratej ve donanma tarihçisi EricGrove'ye aittir (Özgen, 2017: 174). Grove (1990: 236-240), yetenekleri itibariyle dünya donanmalarını dokuz kategoriye ayırmış ve bu ayrıma göre Türk Deniz Kuvvetleri'ni Bitişik Bölge Güç Aktarımı Donanması kategorisinde değerlendirmiştir. Grove'nin çalışmasının yayınladığı tarih 1990'dır. Türk Deniz Kuvvetleri'nin o dönemki yetenekleri dikkate alındığında değerlendirmenin doğru yapıldı ̆̆ kabul edilebilir. Ne var ki aradan neredeyse 30 sene geçmiştir. Bu zaman zarfi içerisinde kuvvet yapısındaki gelişmeler göz önünde bulundurulduğunda bugün Türk Deniz Kuvvetleri'nin bir üst kategori durumundaki Orta Çaplı Bölgesel Güç Aktarımı Donanması kategorisine yükselmenin eşiğinde olduğu söylenebilir. Nitekim başta LHD olmak üzere devam eden projelerin tamamlanmasıyla geçişin gerçekleşeceği hatta artık bir üst kategori durumundaki Orta Çaplı Küresel Güç Aktarımı Donanması olma yolunda ilerlenmeye başlanacağı öne sürülebilir (Özgen, 2017: 174).

2015 y1lında yayınlanan Türk Deniz Kuvvetleri Stratejisi başlıklı güncel strateji belgesinde Türk Deniz Kuvvetleri'nin misyonu, "anavatan savunmasına katkı sağlamak; Türkiye'nin denizlerdeki hükümranlık haklarını, deniz alaka ve menfaatlerini korumak" olarak ifade edilmektedir. Aynı belgede kuvvetin icra edeceği görev nevileri deniz kontrolü, güç intikali, denizden karaya darbe harekât1, denizlerin serbestçe kullanımının engellenmesi, deniz ulaştırmasının korunması, deniz güvenlik harekâtı, deniz yetki alanlarının kontrolü, bayrak ve varlık gösterme, barışı destekleme harekâtı, kolluk harekâtı, muharip olmayanların tahliyesi harekâtı, insani yardım harekâtı, doğal afet yardım harekâtı ve aramakurtarma harekâtı olarak sıralanmaktadır (Türk Deniz Kuvvetleri, 2015: 25).

2015 yılında yayınlanan strateji belgesinde Türk Deniz Kuvvetleri'nin hedeflerine de yer verildiği görülmektedir. Buna göre kuvvet, ana vatanın bekasına 
yönelik tehditleri caydırmayı ve gerektiğinde TSK'nın diğer unsurlarıyla müştereken kesin sonuçlu harbin kazanılmasını, denizlerdeki hükümranlık hakları ile deniz alaka ve menfaatlerinin korunmasını, deniz ulaştırma yollarının güvenliğinin sağlanmasını, Kuzey Kıbrıs Türk Cumhuriyeti (KKTC)'nin savunma ve deniz hak ve menfaatlerinin korunmasının desteklenmesini, çevre denizlerde deniz güvenliğinin tesis edilmesini, yakın çevrede istikrarlı bir güvenlik kuşağ oluşturulmasını ve küresel barışa katkı sağlanmasını, dış politika ve savunma sanayiinin desteklenmesini ve İttifak Deniz Stratejine katkıda bulunulmasını hedeflemektedir. Kuşkusuz belirlenen hedefler hem çevre denizlerde hem de çevre denizlerin ötesinde harekât icra edebilecek tipte ve yetenekte platformların tedarikini gerektirmektedir. Bu tespitten hareketle kuvvet yapısını geliştirmeye önem veren Türk Deniz Kuvvetleri de k1sa (0-5 y11), orta (5-10 y1l) ve uzun (11-20 yıl) vadede tedarik edilecek platformları belirlemiştir. Planlamaya göre kısa vadede Ada Sınıfi korvetler, Türk Tipi hücumbotlar, lojistik destek gemileri, Tank Çıkarma Gemileri (Landing Ship Tank/LST), denizaltı kurtarma ana gemisi, kurtarma yedekleme gemileri, araştırma gemisi, deniz karakol uçakları, genel maksat helikopterleri, insansız hava araçları (IHA'lar) ve insansız/otonom sualtı araçları; orta vadede ise İ Sınıfi firkateynler, hava savunma harbi (HSH) firkateynleri, LHD, muharebe destek gemisi, mayın avlama gemileri ve havadan bağımsız tahrik (HBT) sistemli dizel-elektrik denizaltılar tedarik edilecektir. Uzun vadede ise deniz kontrolü, güç aktarımı ve kuvvet koruma platformlarının sayısının arttırılması öngörülmektedir (Türk Deniz Kuvvetleri, 2015: 31). Öte yandan buraya kadar sıralananlar sadece yeni platformların tedariki ile ilgili hususlardır. Türk Deniz Kuvvetleri, kuvvet yapısının geliştirilmesine yönelik birçok alanda girişimlerde bulunmaktadır ki burada öne çıkan başlıklar mevcut platformların modernizasyonu, yeni silah ve sensör sistemlerinin envantere alınması, nitelikli insan gücünün yetiştirilmesi ve lojistik ve idame olanaklarının iyileştirilmesidir.

Misyonu, görevleri ve hedefleri dikkate alındığında, Türk Deniz Kuvvetleri'nin LHD sınıfi bir platformu ihtiyaç olarak belirlemesinin nedeni ortaya çıkmaktadır. Öyle anlaşılıyor ki gelecekte kuvvet sadece çevre denizlerde değil, çevre denizlerin ötesinde de harekâtlar icra edecektir. Ana vatandan uzak bölgelerde icra edilecek harekâtların olmazsa olmazı ise güç aktarımı yapabilecek tipte ve yetenekte platformların idamesidir. Günümüzde Türk Deniz Kuvvetleri’nin 
güç aktarımı yeteneği büyük ölçüde çevre denizlerle sınırlıdır. LHD, bu yeteneği çevre denizlerin ötesine genişletmeye yönelik bir adımdır. Kaldı ki LHD sadece muharip değil, muharip olmayan görevlerde de kullanılacaktır. Dolayısıyla söz konusu tedarik ile son yıllarda öne çıkan savaş dışı harekâtlar alanında da yetenek artışı sağlanacaktır. $\mathrm{Bu}$ son tespit geçtiğimiz yıllarda icra edilen muharip olmayanların tahliyesi harekâtları üzerinden açılanacak olursa Türkiye, çatışmalardan ötürü 1997'de Arnavutluk'tan, 2006'da Lübnan'dan, 2011'de Libya'dan ve 2015 'te Yemen'den vatandaşlarını denizyoluyla tahliye etmek durumunda kalmıştır. Örneğin Lübnan'daki harekâtta Dz.K.K.lığı'na ait TCG İskenderun Personel Nakliye Gemisi görev almıştır. Tahliye işlemi sorunsuz şekilde tamamlanmıştır (T.C. Dışişleri Bakanlığı, 2006). Ancak bu durum, harekâtın bir amfibi hücum gemisi tarafından çok daha etkin şekilde gerçekleştirileceği gerçeğini değiştirmemektedir ki aynı maksatla Fransız Donanması'nın FS Mistral isimli LHD'yi Lübnan kıyılarına intikal ettirmesi (Naval Technology, t.y.) dikkat çekicidir.

Tarih boyunca donanmaların temel işlevlerinden biri ülke çıkarlarının ana vatanın ötesinden savunulması olmuş, etki ve ilgi alanının genişlemesi her daim deniz gücüne daha fazla kaynak ayrılmasını beraberinde getirmiştir. Deniz gücünü ticari, siyasi ve askeri erişimin aracı olarak gören Alfred T. Mahan'ın (1840-1914) dairesel bir döngü oluşturacak şekilde, "üretimin zenginlik yarattığı, zenginliğin donanmayı finanse ettiği ve donanmanın da ticareti ve üretimi koruduğu" (Holmes, 2011) yönündeki değerlendirmesi son derece önemlidir. Bu çerçevede Türkiye, önümüzde dönemde uluslararası alandaki etkinliğini arttırmayı hedeflediğini hemen her platformda dile getirmektedir. Konunun siyasi ve askeri boyutları bir yana bırakılsa dahi ekonomik ve ticari açıdan dünya ile giderek daha fazla entegre olan, yurtdışında mali değeri milyarlarca dolara ulaşan yatımları bulunan ve dış ticaret yüklerinin taşınmasında deniz ulaştırma yollarına bağımlılığı her geçen gün artan Türkiye'nin donanmasının yeteneklerini geliştirmesi makul ve gerçekçi bir tercihtir. 


\section{Uçak Gemisi İhtiyacı ve LHD}

Çalışmanın konusu itibariyle LHD'nin asıl üzerinde durulması gereken özelliği gerektiğinde uçak gemisi rolünü de üstlenebilecek olmasıdır. Günümüz deniz harekâtlarında hava desteğinin kritik önemi haizdir. Hatta hava desteğinden yoksun bir deniz kuvvetinin muharebe ortamındaki etkinliğinin büyük ölçüde azalacağı hususunda genel bir mutabakattan bahsedilebilir. Bu açıdan bakıldığında çevre denizlerdeki harekâtlarda Türk Deniz Kuvvetleri unsurlarının ihtiyaç duyacağı hava desteğinin bir ölçüde Türk Hava Kuvvetleri’ne ait uçaklar tarafından sağlanması mümkündür. Ancak uçakların menzillerinin ve havada kalış sürelerinin sınırlılığı düşünüldüğünde kıyı sularından uzaklaştıkça hava desteğinin etkinliğinin azalacağı, belli bir noktadan sonra ise zaten hiç mümkün olmayacağı ortadadır. Gerçi tanker uçakları ile havada yakıt ikmali yapılarak uçakların harekât yarıçapı ve havada kalış süresi uzatılabilir. Ancak başka ülkelerin hava sahalarının kullanılmasının gerekeceği durumlar bir yana düşman hava sahasında ve yüksek tehdit ortamında bunun ne ölçüde yapılabileceği tartışmalıdır.

Türk Deniz Kuvvetleri, LHD ile beraber STOVL uçaklarının tedarikini de gündemine almış bulunmaktadır. Tedarikin gerçekleşmesi durumunda organik deniz havacılığının eksik kalan parçası tamamlanmış olacak, böylece kara konuşlu uçakların erişebileceği azami harekât yarıçapı dışında görev icra eden dost unsurlara da hava desteğinin sağlanması mümkün hale gelecektir. Ayrıca tedarik başta denizden karaya darbe harekâtı olmak üzere taarruz görevlerinde de yetenek artış1 sağlayacaktır. Bu bağlamda merkezinde LHD’nin yer alacağı bir görev kuvvetinin Adalar Denizi ve Karadeniz'de olmasa da Akdeniz harekât alanında muhasım unsurlara karşı etkin şekilde kullanılabileceği değerlendirilmektedir. Örneğin Yunanistan ile yaşanabilecek bir savaşta ters istikamette bir cephe açılabilecek, böylece karşı taraf kuvvetlerini bölmek durumunda kalacaktır. Kaldı ki böyle bir yeteneğin dış politikayı destekleme ve çok uluslu barışı destekleme harekâtlarındaki ağırlığı arttırma gibi ilave getirilerinin olacağ 1 da unutulmamalıdır. (Özgen, 2015: 449). Nitekim bir söyleşisinde Türk Donanması'nın kuvvet yapısında sabit ve döner kanatlı hava araçlarının konuşlanabildiği platformların yer almamasını eksiklik olarak değerlendiren eski Deniz Kuvvetleri Komutanı Emekli Oramiral Salim Dervişoğlu'nun, bu yeteneğe 
erişime yönelik planlamaların bilhassa koalisyon harekâtları için yapılması gerektiğini ifade etmesi son derece önemlidir (Akçadağ, 2011: 7-8).

Diğer taraftan son zamanlarda Ankara-Washington hattında tırmanan gerilim ve Trump yönetiminin ABD Kongresi'nin Türkiye'ye silah satışının geçici süreliğine askıya alınmasını da öngören 2019 yılı Ulusal Savunma Yetkilendirme Yasası'nı onaylaması (BBC Türkçe, 2018), kaçınılmaz şekilde F-35B'lerin tedariki hususunda soru işaretlerinin ortaya çıkmasına neden olmaktadır. Kuşkusuz LHD'nin uçak gemisi görevlerini icra edebilmesi gerekli sabit ve döner kanatlı hava araçlarının tedarikine bağlıdır. Türk Deniz Kuvvetleri'nin envanterinde yer alan helikopterlerin ihtiyacın bir boyutuna cevap vereceği muhakkaktır. Kaldı ki uluslararas1 silah piyasas1 muhtemel bir ambargo durumunda envanterdeki ABD menşeli helikopterlerin yerini alabilecek alternatifler de sunmaktadır. Buna karşılık uçak meselesi çok farklıdır. Günümüzde yeni nesil platformlar içerisinde STOVL harekâtına uygun yegâne uçak F-35B'dir. Gerçi kullanım fazlası $A V-8 B$ Harrier II'lerin tedariki de düşünülebilir ki bir süre önce Batı basınından Türkiye'nin bu yönde İngiltere ve ABD nezdinde girişimlerde bulunduğuna dair haberler yayımlanmıştır (Herschelman, 2017b). Fakat faydalı hizmet ömürlerinin sonuna yaklaşan Harrier'lar sadece geçici bir çözüm oluşturabilir. F-35B'lerde sorun çıkaran ABD'nin Harrier'ların transferine müspet yönde yaklaşacağını beklemek de gerçekçi değildir.

Aslına bakılırsa ABD onay da verse F-35B'lerin doğru bir tercih olup olmadığı üzerine tartışmak gerekir. Öyle ki F-35B esasen ABD ve müttefiklerinin ihtiyaçları göz önünde bulundurularak geliştirilmiş bir uçaktır. Daha ziyade ABD öncülüğündeki bir koalisyon bünyesinde görev yapması öngörülen bu uçağın etkin kullanımı hiç şüphesiz Washington ile müspet ilişkilerin tesisine ve büyük boyutlu çıkar çatışması yaşanmamasına bağlıdır. Günümüzde Türkiye-ABD ilişkilerinin durumu ortadadır. Velev ki belli bir yumuşama da yaşansa, ikili ilişkilerin Soğuk Savaş ya da en azından 1990'lı yıllardaki gibi olmayacağı öngörülebilir. $\mathrm{Bu}$ koşullarda Türkiye'nin F-35B'lerden ulusal hedef ve çıkarları doğrultusunda ne ölçüde verim alabileceği her daim bir muamma olarak kalacaktır. Ne var ki kullanıcının harekât ihtiyaçları ve görünür gelecekte başka bir alternatif bulmanın olanaksızlığı dikkate alındığında “şartlar elverirse” Türk Deniz Kuvvetleri'nin uçak 
gemisi harekâtında tecrübe kazanması amacıyla $\mathrm{F}-35 \mathrm{~B}$ veya $\mathrm{AV}-8 \mathrm{~B}$ tedariki gerçekleştirilebilir.

2015 yılında yayımlanan strateji belgesinde Türk Deniz Kuvvetleri açıkça Orta Çaplı Küresel Güç Aktarımı Donanması yeteneğine sahip bir kuvvet yapısını hedeflediğini deklare etmiştir (Türk Deniz Kuvvetleri, 2015). Bu kategorideki donanmaların kuvvet yapılarında uçak gemileri, amfibi hücum gemileri, muhrip ve firkateynler, nükleer denizaltılar ve lojistik destek gemileri yer almaktadır. Nitekim bu tip donanmaların özelliği, bağımsız şekilde kıyı sularının ötesinde ve yakın okyanus alanlarında büyük çaplı ve yüksek yoğunluklu bir deniz harekâtını icra edebilecek imkân ve kabiliyetlere sahip olmalarıdır (Grove, 1990: 238). Türk Deniz Kuvvetleri'nin mevcut ve gelecekte planlanan kuvvet yapısı dikkate alındığında sıralanan platformlar içerisinde eksik kalanların uçak gemisi ile nükleer denizaltı başlıkları olduğu görülmektedir. Nükleer denizaltılar başka bir çalışmanın konusudur. Uçak gemisi hususunda ise akla ilk gelen soru "tedarik edilen LHD bu ihtiyacı karşılamıyor mu?" olmaktadır. Hemen belirtmek gerekir ki LHD, son tahlilde temel tasarım amacı çıkarma harekâtları olan bir amfibi hücum gemisidir. Türk Deniz Kuvvetleri'nin deklare ettiği hedefler bir yana sadece doktrinsel açısından bile bakıldığında kuvvet yapısına dâhil olması uçak gemisi ihtiyacının sona ermeyeceğini göstermektedir.

Uçak gemisi ihtiyacı noktasında tereddüt kalmadığına göre tasarım özellikleri üzerine düşünmek gerekir. Uçak gemisi tasarımında başlangıç parametresini görev ve görevin operasyonel senaryosu oluşturmakta, buradan hareketle de taşınacak uçak sayısı ve tipleri, günlük sorti sayısı ve ikmal bütünlemesiz harekât süresi belirlenmektedir. Doğal olarak uçak sayısı arttıkça geminin boyutları büyümekte ve personel ihtiyacı fazlalaşmaktadır (Çelebi, Cin, Özer ve Donbaloğlu, 1999: 473). Bunlar da ilk alım ve bakım-idame maliyetlerini arttırmaktadır. Tasarım aşamasında harekât ihtiyaçları ile maliyet arasında optimum bir denge kurulması esastır.

Türk Deniz Kuvvetleri açısından bakıldığında uçak gemisinin gerek ulusal gerekse uluslararası harekâtlardaki birincil görevinin merkezinde yer alacağı görev kuvveti ve görev gruplarına hava şemsiyesi sağlamak olacağı söylenebilir. İyimser bir tahminle uçak gemisinde konuşlu uçakların \%75'inin göreve hazır olacağ öngörülebilir. Hesaplama bir uçağın günde iki sorti gerçekleştireceği 
varsayımından hareketle yapıldığında 7/24 esasına göre icra edilecek 2'şer saatlik muharebe hava devriye (Combat Air Patrol/CAP) görevleri için 8 uçağa ihtiyaç olacağı ortaya çıkmaktadır. CAP görevlerinin bir değil, en az iki uçakla icra edildiği düşünüldüğünde ise pratikte bu sayı 16 olacaktır. Diğer yandan harekâtın süresi uzadıkça göreve hazırlık oranının düşeceği, bunun da ihtiyaç duyulan uçak sayısına yansıyacağı dikkate alınmalıdır. Tabi ki buraya kadar sadece CAP görevi için gereken minimum yeteneklere odaklanılmıştır. Planlama yapılırken taarruz, havadan erken ihbar (Airborne Early Warning/AEW), denizaltı savunma harbi (DSH), keşif ve gözetleme, muharebe arama-kurtarma (Combat Search and Rescue/CSAR) ve nakliye görevleri için de ayrıca hesaplama yapılması gerekecektir. $\mathrm{Bu}$ isterler doğrultusunda DSH ve nakliye helikopterlerinin görev grubundaki diğer muharip ve lojistik destek gemilerine konuşlandırılabileceği düşünülerek tasarım aşamasında 30-40 kadar uçak, helikopter ve İHA taşıyabilen ve 7 gün boyunca ikmal bütünlemesiz harekât icra edebilen, takribi 30.000-40.000 ton deplasmana sahip bir konvansiyonel uçak gemisinin referans alınabileceği değerlendirilmektedir. Elbette periyodik bakım uygulamaları ve eğitim faaliyetleri sırasında harekâttan sakıt kalınacağı göz önünde bulundurularak tedarik planlaması en az iki platforma göre yapılmalıdır.

Kuşkusuz uçak gemisi tasarımında belirlenmesi gerekecek en kritik hususlardan biri de iniş-kalkış konfigürasyonu olacaktır. Aslında LHD tecrübesi de göz önünde bulundurulduğunda en risksiz seçim STOVL gibi durmaktadır. Ancak seçimin bu yönde olması daha önce altı çizilen uçak tedariki ve idamesinde tek bir ülkeye bağımlılıktan kaynaklanacak sorunları gündeme getirecektir. Ayrıca STOVL tipi uçakların bazı dezavantajları olduğu da göz ardı edilmemelidir. Bu durumda seçenek sayısı ikiye inmektedir: CATOBAR veya STOBAR. Aslında STOBAR'ın da harekât ihtiyaçlarını karşılayacağı söylenebilir. Bununla birlikte farklı tipte hava araçlarının konuşlanmasına uygun yapısı ve uçakların performansından maksimum ölçüde verim alınmasını sağlaması CATOBAR'ı bir adım öne çıkarmaktadır. Gerçi mancınık konusunda ABD'nin tekel konumunda olması, STOVL özelindekine benzer kaygıları gündeme getirebilecektir. Ancak ABD’nin geçmişte Fransa'ya buharlı mancınık satışı yaptığı bilinmektedir. Yine kısa bir zaman önce Hindistan'a EMALS satışına onay verilmesi (Bedi, 2017) ve bu yeni sisteme Fransa, Brezilya ve Japonya'nın ilgi duyduğunun bizzat üretici 
firma General Atomics tarafından açıklanması (NavyRecognition, 2017) mancınık teknolojisine erişimin mümkün olabileceğini göstermektedir. Kaldı ki Çin, önümüzdeki dönemde hizmete alacağ konfigürasyonuna geçiş yapmayı planlamakta ve bu amaçla hem buharlı hem de elektro manyetik mancınık teknolojisi üzerine çalışmalar yürütmektedir (Chuanren, 2017) Dolayısıyla olası bir engelleme karşısında tamamen alternatifsiz kalınmayacağı değerlendirilmektedir.

Aslında konu EMALS olduğunda nasıl tedarik edileceği kadar nasıl çalıştırılacağı sorusu da önem taşımaktadır. Zira bazı kaynaklarda sistemin çok yüksek miktarda elektrik enerjisine ihtiyaç duyduğu hatta günümüz teknolojiyle bunun konvansiyonel tahrik sistemleriyle üretilmesinin mümkün olmadığ 1 bilgisi yer almaktadır (Sodhi, 2015: 7). Buna karşılık olarak General Atomics' in EMALS'in küçük boyutlu ve konvansiyonel tahrikli platformlarda da kullanılabileceği yönündeki açıklamasının altı çizilmelidir (NavyRecognition, 2017). Keza Çin kaynakları da yeni geliştirdikleri entegre tahrik sistemi sayesinde kendi çözümlerinin nükleer reaktör ihtiyacını ortadan kaldırdığını açıklamışlardır (Dominguez ve O’Connor, 2017). Buna rağmen bazı uzmanların konvansiyonel tahrik sistemi ile birlikte kullanıldığında EMALS'in ilave yakıt ve enerji sarfiyatına neden olduğu ve geminin muharebe kabiliyetini azalttığı yönündeki tespitlerini göz ardı etmemek gerekir (Chuanren, 2017) Bu şartlarda hangi mancınık çözümünün seçileceği noktasındaki nihai kararın askeri-teknik incelemelerden sonra verilmesi en doğrusudur.

CATOBAR tipi uçak gemisi denildiğinde hemen herkesin aklına Amerikan Donanması'nın envanterindeki 100.000 tonluk nükleer tahrikli platformlar gelmektedir. Lakin unutulmamalıdır ki böyle bir platforma yönelmek zorunluluk değil, tercih meselesidir. CATOBAR tipi platformların illa bu özellikleri taşıyacağına dair bir kural olmadığı gibi Türkiye özelinde buna gerek de yoktur. Brezilya'nın 2017 yılında hizmet dışına çıkarma kararı aldığı CATOBAR tipi Clemenceau sınıfı Sao Paulo (ex-Foch) isimli uçak gemisinin boyu 265 metre, deplasman1 32.800 tondur (Steward, 2018). Keza 1990'11 yılların ortalarında İspanya'da yerleşik Bazan Tersanesi'nin Çin'e teklif ettiği düşük maliyetli CATOBAR tasarımlarından SAC-200'ün boyu 221.8 metre, deplasmanı 23.000 ton; SAC-220'ün ise boyu 240 metre, deplasman1 25.000 tondur (Storey ve Ji, 
2004). Dikkat edilecek olursa sıralanan platformlardan bazılarının deplasmanları TCG Anadolu'dan bile daha düşüktür. Benzer özellikleri haiz yeni tasarımlar pekâlâ Türk Deniz Kuvvetleri için de düşünülebilir.

Son olarak CATOBAR tipi uçak gemisinde karar kılınması doğal olarak bu tip platformlarda harekât icra edebilecek uçak tedarikini de gündeme getirecektir. Burada ilk akla gelebilecek yurt dışından hazır alıma yönelmektir. Fakat son yıllarda savunma sanayiinin gelişimine önem veren ve TSK'nın ihtiyaçlarını mümkün mertebe yurt içinden karşılamayı hedefleyen Türkiye açısından bu durum kabul edilebilir değildir ya da en azından ilk seçenek olmamalıdır. Bu şartlarda yurt içi bir çözüm üzerine düşünmek gerekir. Fransa'nın Rafale $M$ veya Rusya'nın Sukhoi Su-33 örneklerinde olduğu gibi günümüzde uçak gemisi konuşlu uçakların birçoğu kara konuşlu uçaklar üzerinden geliştirilmiştir. Nitekim maliyet faktörü göz önünde bulundurulduğunda ayrı bir proje yürütmek yerine halen Milli Muharip Uçak (MMU) Projesi altında TUSAŞ'ın İngiltere'nin BAE Systems firmasıyla işbirliği yaparak tasarım çalışmalarına devam ettiği TF-X'in donanma versiyonunun (TF-X Deniz/TF-X Maritime) geliştirilmesi rasyonel bir seçenek olarak öne çıkmaktadır. Bugün için TF-X olarak adlandırılan uçağın gelecekte farklı bir ortak geliştirme projesine katılma ya da mevcut bir platformun milli aviyonik, motor ve silah sistemleri ile teçhiz edilmesi şeklinde de tedariki gündeme gelse aynı seçeneğe yönelinebileceği değerlendirilmektedir.

\section{Sonuç}

Türk Deniz Kuvvetleri, Soğuk Savaş sonrası değişen harekât ihtiyaçları doğrultusunda 1990'lı yılların ikinci yarısında uçak gemisi tedarikini gündemine almıştır. Ne var ki ilerleyen süreçte yapılan tedarik planlamasında önceliğin LPD sınıfı platforma verilmesi kararlaştırılmış ve çalışmalar bu yöne kaydırılmıştır. Aslına bakılırsa 2005 yılında LPD ismiyle resmen başlatılan proje, sınırlı hava gücü kapasitesi sunan bir amfibi hücum gemisinin tedarikini öngörmektedir. Ancak 2010 yılında harekât ihtiyaçlarının yeniden belirlenmesi, özellikle de hava gücü kapasitesinin arttırılmasının istenmesiyle tedarik edilecek platformun tasarımı ve yetenekleri tamamen değişmiştir. Bu minvalde 2015 yılında Çok Maksatlı Amfibi Hücum Gemisi Projesi ismiyle imzalanan sözleşme altında tedariki öngörülen 
platform artık LHD sınıfı bir amfibi hücum gemisidir. 2016 yılında inşa çalışmalarına başlanılan ve TCG Anadolu adı verilen platformun en dikkat çekici özelliği ise şüphesiz STOVL tipi uçakların harekâtına imkân tanıması dolayısıyla gerektiğinde uçak gemisi rolünü de üstlenebilmesidir.

Türkiye'nin uçak gemisine ihtiyacı olup olmadığı tartışmaları uzun yıllardır yapılmakta, tedarike ilişkin hem müspet hem de menfi yönde yorumlarla karşılaşılmaktadır. Hemen belirtmek gerekir ki bu çalışmada Türkiye'nin uçak gemisine ihtiyacı olduğu savunulmaktadır. $\mathrm{Bu}$ görüşün savunulmasının temel gerekçesi Türk Deniz Kuvvetleri'nin genişleyen harekât yarıçap1 ve buna koşut olarak da çevre denizlerin ötesinde görev yapabilecek tipte ve yetenekte platformların hizmete alınması ihtiyacının artmasıdır. Günümüzde uçak gemileri açık deniz harekâtlarının olmazsa olmazıdır. Dolayısıyla Türk Deniz Kuvvetleri'nin uçak gemisi tedarikini gündemine alması doğru bir hareket tarzıdır.

Öte yandan hâlihazırda inşa çalışmaları devam eden LHD, ana tasarım amacı çıkarma harekâtları olan bir amfibi hücum gemisidir. Uçak gemisi harekâtında tecrübesi olmayan Türk Deniz Kuvvetleri açısından iyi bir başlangıç teşkil edeceğine şüphe yoktur. Hatta ikinci bir platformun tedariki de mutlaka gerçekleştirilmelidir. Ancak yönünü açık denizlere çevirmiş ve Orta Çaplı Küresel Güç Aktarımı Donanması kategorisine yükselme iradesini deklare etmiş Türk Deniz Kuvvetleri'nin nihai hedefi doğrudan uçak gemisi olarak tasarlanmış platformların tedariki olmalıdır. Bu çerçevede harekât ihtiyaçları ve maliyet arasındaki optimum denge gözetilerek 30-40 kadar uçak, helikopter ve İHA taşıyabilen ve 7 gün boyunca ikmal bütünlemesiz harekât icra edebilen, takribi 30.000-40.000 ton deplasmana sahip CATOBAR tipi iki konvansiyonel uçak gemisinin kuvvet yapısına dahil edilebileceği değerlendirilmektedir. Muharip uçak olarak ise yurt dışı bir çözüme yönelmektense öncelikle halen Türk Hava Kuvvetleri için tasarım çalışmaları devam eden TF-X'in donanma versiyonunun geliştirilmesi üzerine yoğunlaşılabileceği düşünülmektedir.

\section{Extended Summary}

The aim of this study is to evaluate the procurement of aircraft carrier for the Turkish Naval Forces. In this context, debates about procurement of aircraft 
carrier for the Turkish Naval Forces are widely found in visual and written press. In fact, history of the debates dates back to the mid-1990s. However, subject heading entered the public agenda after the start of the Multi-Purpose Amphibious Assault Ship Project, especially when President Erdoğan stressed the importance of possessing aircraft carrier and Turkey's shortcoming in this area. Today, aircraft carriers are at the center of a debate, considering operational requirements of the Turkish Naval Forces. Thus, one part expresses support for aircraft carrier procurement, while other part rejects.

Aircraft carrier can shortly be defined as warship from which aircrafts may take-off and land. There are three configurations of aircraft carriers in terms of technique used for the launch and recovery of aircraft from the deck: Catapult Assisted Take-Off Barrier Arrested Recovery (CATOBAR), Short Take-Off Barrier Arrested Recovery (CATOBAR) and Short Take-Off Vertical Landing (STOVL). There are also amphibious assault ships, classified as Landing Helicopter Dock (LHD), Landing Helicopter Assault (LHA) and Landing Platform Helicopter (LPH) that possess the capability to deploy STOVL aircrafts. Despite some negative aspects, ownership of an aircraft carrier still continues its importance. Currently, there are 37 active aircrafts carriers around the world within twelve navies, including amphibious assault ships.

Turkey has begun the construction of a LHD, named TCG Anadolu under the Multi-Purpose Amphibious Assault Ship Project on April 30, 2017. The vessel will be 231 meters long and displace 27.436 tons, when fully loaded. In fact, LHD is an amphibious assault ship, which designed to transport troops, vehicles and supplies for the perform of landing operations. However, it will also be able to deploy STOVL aircrafts for carrier-based operations. Thus, procurement of STOVL aircrafts like F-35Bs is on the agenda of Turkey.

Expansion of the Turkish Navy's radius of operation became a reality in the post-Cold War era. Therefore, when planning future force structure, it is important to procure and maintain platforms with the ability to operate beyond the homeland. In terms of planning to develop force structure, overseas power projection is the critical capability. TCG Anadolu will be able to project power not only in surrounding seas but also in high seas. The ship will also able to serve as 
aircraft carrier when needed. It is clear that a significant gap will be filled with this procurement.

As a result, necessity of aircraft carrier acquisition for the Turkish Naval Forces and propriety of the Multi-Purpose Amphibious Assault Ship Project have been argued in the study. In addition, procurement of classical aircraft carrier, CATOBAR type for the Turkish Naval Forces has been suggested in the study. Lastly, development of naval version of the TF-X, TF-X Maritime that is suited for carrier-based operations has also been suggested in the study.

\section{Kaynakça}

\section{Kitaplar}

Fontenoy, P. E. (2006). Aircraft Carriers: An IIIustrated History of Their Impact. Santa Barbara: ABC-Clio.

Friedman, G. ve Friedman, M. (2015). Savaşın Geleceği: 21. Yüzyılda, Güç, Teknoloji ve Amerikan Dünya Egemenliği. İstanbul: Pegasus Yayınlar1.

Grove, E. (1990). The Future of Sea Power. Londra: Routledge.

Gürdeniz, C. (2013). Hedefteki Donanma. İstanbul: Kırmızı Kedi Yayınevi.

Hart, B. L. (2015). İkinci Dünya Savaşı Tarihi. (Çev. K. Bağraçık), İstanbul: Türkiye İş Bankası Kültür Yayınları.

Hendrix, J. (2015). The Rise and Fall of Carrier Aviation, Washington: Center for a New American Security.

Özgen, C. (2015). Rota: Deniz Kuvvetleri ve Enerji Güvenliği. Ankara: Gece Kitaplı̆̆ 1 .

Sommerville, D. (2012). II. Dünya Savaşı. (Çev. A. Önsan), İstanbul: Türkiye İş Bankası Kültür Yayınları.

Till, G. (2004). Seapower: A Guide for the Twenty-First Century. Londra: Frank Case.

Topuz, S. (2016). Modern Deniz Harbini ve Denizler İçin Mücadeleyi Anlamak. Ankara: Alibi Yayınc1lık. 


\section{Makaleler}

Allison, G. (2017). Aircraft Carrier HMS Queen Elizabeth Commissioned into the Royal Navy. 17 Şubat 2018'de https://ukdefencejournal.org.uk/aircraftcarrier-hms-queen-elizabeth-commissioned-royal-navy/ adresinden alınmıştır.

Atakl1, C. (2017). Bir Tweet Attım Akılsızlı̆ğ ve Cehaletin Boyutunu Gördüm. 05 Eylül 2018'de https://www.sozcu.com.tr/2017/yazarlar/can-atakli/birtweet-attim-akilsizligin-ve-cehaletin-boyutunu-gordum-1920000/ adresinden alınmıştır.

Bedi, R. (2017). US Offers EMALS Technology to India for IN's Proposed Second Indigenous Carrier. 06 Eylül 2018'de https://www.janes.com/ article/75051/us-offers-emals-technology-to-india-for-in-s-proposedsecond-indigenous-carrier adresinden alınmıştır.

Chen, C. P. (t.y.). World War II Database: HMS Hermes, 10 Şubat 2018'de https://ww2db.com/ship_spec.php?ship_id=160 adresinden alınmıştır.

Chuanren, C. (2017). China Explores Electromagnetic Carrier Launch System. 08 Eylül 2018'de https://www.ainonline.com/aviation-news/defense/2017-0706/china-explores-electromagnetic-carrier-launch-system adresinden alınmıştır.

Cohen, Z. (2015). Report: U.S. Aircraft Carriers Could Become Ineffective. 20 Mart 2018'de https://edition.cnn.com/2015/11/03/politics/aircraft-carriersreport-future/index.html adresinden alınmıştır.

Çelik, H. (2013). Uçak Gemisine İhtiyaç Var mı?.05 Eylül 2018'de http://www.posta.com.tr/yazarlar/hakan-celik/ucak-gemisine-ihtiyac-varmi-155491 adresinden alınmıştır.

Dominguez, G. ve O'Connor, S. (2017). China Reveals More Details About Locally Developed Electromagnetic Catapult. 08 Eylül 2018'de https:/www.janes.com/article/75775/china-reveals-more-details-aboutlocally-developed-electromagnetic-catapult adresinden alınmıştır.

Erickson, A. S. Denmark, A. M. ve Collins, G. (2012). Beijing's "Starter Carrier" and Future Steps: AlternativesandImplications. Naval War College Review, 65 (1), 14-55. 
Farley, R. (2014). Doesthe US Navy Have 10 or 10 Aircraft Carriers?. 20 Mart 2018'de https://thediplomat.com/2014/04/does-the-us-navy-have-10-or-19aircraft-carriers/ adresinden alınmıştır.

Gürdeniz, C. (2017). Cumhuriyet Donanması ve Uçak Gemisi İhtiyacı. 10 Şubat 2018 'de https://www.aydinlik.com.tr/kose-yazilari/cem-gurdeniz/2017temmuz/cumhuriyet-donanmasi-ve-ucak-gemisi-ihtiyaci adresinden alınmıştır.

Harding, T. (2012). Aircraft Carrier Costs Will be Half What You Think, US Tells Ministers. 05 Eylül 2018'de https://www.telegraph.co.uk/news/ uknews/defence/9164155/Aircraft-carrier-costs-will-be-half-what-youthink-US-tells-ministers.html adresinden alınmıştır.

Herschelman, K. (2017a). Turkey Expresses Interest in Buying F-35B STOVL Variant. 7 Mart 2018'de http://www.janes.com/article/ 75300/turkeyexpresses-interest-in-buying-f-35b-stovl-variant adresinden alınmıştır.

Herschelman, K. (2017b). Turkey Seeks to Buy Harriers as an Interim Measure Until F-35Bs are Ready. 02 Eylül 2018'de https://www.janes.com/article/76200/turkey-seeks-to-buy-harriers-as-aninterim-measure-until-f-35bs-are-ready adresinden alınmıştır.

Holmes, J. R. (2011). What Makes China "Mahanian"?.07 Eylül 2018'de https://thediplomat.com/2011/11/what-makes-china-mahanian/ adresinden alınmıştır.

Kahlon, A. S. Gupta, T. Dahiya, P. ve Chaturvedi, S. K. (2017). A Brief Review on Electromagnetic Aircraft LaunchSystem, International Journal of Mechanical and Production Engineering, 5 (6), 58-67.

Kılıç, H. (2018). Uçak Gemisine İhtiyacımız Var mı?.07 Eylül 2018'de http://www.kokpit.aero/turkiyenin-ucak-gemisine-ihtiyaci-var-mi adresinden alınmıştır.

Kubo, N. ve Kelly, T. (2017). Japon Considers Refitting Helicopter Carrier for Stealth Fighters: Government Sources, 15 Şubat 2018'de https:// www.reuters.com/article/us-japan-defence-carrier/japan-considersrefitting-helicopter-carrier-for-stealth-fighters-government-sourcesidUSKBN1EK0CF adresinden alınmıştır. 
Li, N. ve Weuve, C. (2010). China's Aircraft Carrier Ambitions. Naval War College Review, 63 (1), 13-32.

Millar, J. (2017). HMS Prince of Wales Aircraft Carrier 'Floats Out' Majestic Photos Show Huge New Ship. 17 Şubat 2018'de https:// www.express.co.uk/news/uk/895693/hms-prince-of-wales-floats-out-navyroyal-navy adresinden alınmıştır.

Mönch TR. (1998). Deniz Kuvvetleri Komutanlığı. Savunma ve Havacılık, 12 (70), 36-47.

Mönch TR. (2000). Türk Deniz Kuvvetleri'ne LPD. Savunma ve Havactlı, 14 (79), 91.

Mönch TR. (2010). Denizcilik Türk'ün Milli Ülküsü Olmalıdır. Savunma ve Havacılık, 24 (139), 8-39.

Özgen, C. (2017). Türk Deniz Kuvvetleri Stratejisi’nde Dönüşüm ve Bir Uygulama Örneği Olarak Türk Deniz Görev Grubu. Sosyal Bilimler Dergisi, 4 (12), 167-182.

Peruzzi, L. (2017). First Steel Cut for Italian Navy's New LHD. 14 Şubat 2018'de http://www.janes.com/article/72321/first-steel-cut-for-italian-navy-s-newlhd adresinden alınmıştır.

Pleasance, C. (2017). Russia Plans to Built the World's Largest Aircraft Carrier the Size of Three Football Fields to Take on the US, 14 Şubat 2018'de http://www.dailymail.co.uk/news/article-4440760/ Russia-plans-buildworld-s-biggest-aircraft-carrier.html adresinden alınmıştır.

Polat, S. (2017). Uçak Gemisi. 10 Şubat 2018'de https://www.aydinlik. com.tr/ucak-gemisi-soner-polat-kose-yazilari-agustos-2017 adresinden alınmıştır.

Rao, A. (2017). INS Viraat Decommissioned: Indian Navy Faces Huge Gap in its Fire Power, but Future Looks Hopeful. 17 Şubat 2018'de http://www.firstpost.com/india/decommissioning-of-ins-viraat-is-atemporary-setback-to-indias-naval-power-projection-3319590.html adresinden alınmıştır.

Sağdıç, K. (2017). 21. Yüzyılda Nasıl Bir Donanma. İçinde D. Karakaya (Ed.), Türk Deniz Gücünün 21. Yüzyıl Boyutu(ss. 73-85). İstanbul: Koç Üniversitesi Yayınları. 
Seidel, J. (2017). China is About to Launch Its Second Aircraft Carrier, O01A, 15 Şubat 2018'de http://www.news.com.au/technology/ innovation/china-isabout-to-launch-its-second-aircraft-carrier-001a/ news-story/ce97a88eba 53b00ea37892698b12504c adresinden alınmıştır.

Steward, O. (2018). Why is Brazil Buying HMS Ocean Anyway. 4 Eylül 2018'de https://ukdefencejournal.org.uk/why-is-brazil-decommissioning-its-ownaircraft-carrier-and-buying-hms-ocean/ adresinden alınmıştır.

Storey, I. ve Ji, Y. (2004). China's Aircraft Carrier Ambitions. 3 Eylül 2018'de https://www.globalsecurity.org/military/library/report/2004/ art6-w04.htm adresinden alınmıştır.

Sünnetçi, İ. (2016). TCG Anadolu LHD Gemisinin İnşasına Fiilen Başlandı. Savunma ve Havacilk, 30 (173), 87-92.

Sünnetçi, İ. (2015). LPD Projesinde İmzalar Atıldı. Savunma ve Havacılı, 29 (168), 147-149.

Till, G. (2004). Seapower: A Guide for the Twenty-First Century. Londra: Frank Cass.

\section{Ansiklopediler}

Atalan, S. (2015). Uçak Gemileri. Dünya Askeri Teknolojiler Ansiklopedisi, Modern Deniz Sistemleri: Harp Gemileri içinde (ss. 34-51). İstanbul: DStil.

\section{Raporlar}

Akçadağ, E. (2015). Denizlerin Önemi ve Türk Deniz Kuvvetleri (Rapor No: 68). İstanbul: BİLGESAM Yayınları.

Hendrix, H. J. (2013). At What Cost a Carrier? (Disruptive Defense Papers). Washington: Center for a New American Security.

IISS. (2017). The Military Balance (TheAnnual Assessment of Global Military Capabilities and Defence Economics). Londra: International Institutefor Strategic Studies.

Sodhi, H. (2015). Electro Magnetic Aircraft Launch System. New Delhi: Centre for Air Power Studies. 


\section{Belgeler}

Türk Deniz Kuvvetleri. (1997). Açık Denizlere Doğru: Türk Deniz Kuvvetleri Stratejisi, Deniz Kuvvetleri Dergisi Ek'i, 570.

\section{Bildiriler}

Çelebi, M. S. Cin, S. Özer, S. ve Donbaloğlu, B. (1999). Uçak Gemilerinin Genel Dizayn Parametreleri Üzerine. A.İ. Algoğan, Y. Ünsan ve E. Bayraktarkatal (Ed.), Gemi İnşaatı ve Deniz Teknolojisi Teknik Kongresi Bildiriler Kitabı İçinde (ss. 463-477). İstanbul: Yapım Matbaacılık.

\section{Söyleşiler}

Akçadağ, E. (2011). Gelişen ve Değişen Türk Deniz Kuvvetleri'nin Bugünü ve Yarını (E. Oramiral Salim Dervişoğlu ile Söyleşi). 9 Eylül 2018'de http://www.bilgesam.org/Images/Dokumanlar/0-23-2014040742 bilgesoylesi9.pdf adresinden alınmıştır.

\section{Yazarı Belli Olmayan Web Sitesi Makaleleri}

Armada Espanola. (t.y.) LHD Juan Carlos I (L-61). 10 Şubat 2018'de http://www.armada.mde.es/ArmadaPortal/page/Portal/ArmadaEspannola/b uquessuperficie/prefLang-en/02lhd-juan-carlos-i--03lhd-juan-carlos-i-1-61 adresinden alınmıştır.

BBC Türkçe. (2018). Trump, F-35 Savaş Uçaklarının Türkiye’ye Teslimatını Geçici Olarak Durdurdu. 2 Eylül 2018'de https://www.bbc.com/turkce/haberler-dunya-45177494 adresinden alınmıştır.

C4 Defence. (2018). TCG Trakya Geliyor. 2 Eylül 2018'de http://www. c4defence.com/Gundem/tcg-trakya-geliyor/6374/1 adresinden alınmıştır.

Defence Industry Daily. (2014). France's PA2/CVF Carrier Project: Stalled in France, Hedged on Demand from Brazil?, 14 Şubat 2018'de https://www.defenseindustrydaily.com/france-steaming-ahead-on-pa2cvfcarrier-project-01621/ adresinden alınmıştır. 
Defence Industry Daily. (2016). Egypt Buys Mistrals; Kitting Out With KA-\&KA$52 K, 9$ Şubat 2018'de https://www.defenseindustrydaily.com/ russia-toorder-french-mistral-lhds-05749/ adresinden alınmıştır.

Defence Industry Daily. (2017). The Dokdo Class: An LHD for the ROK. 17 Şubat 2018'de https://www.defenseindustrydaily.com/aegis-awd-lhd-for-rok03431/ adresinden alınmıştır.

General Atomics. (t.y.). Electromagnetic Aircraft Launch System (EMALS). 5 Eylül 2018'de http://www.ga.com/electromagnetic-aircraft-launch-system adresinden alınmıştır.

Global Security. (2011a). IJN Wakamiya Seaplane Carrier, 10 Şubat 2018'de https://www.globalsecurity.org/military/world/japan/wakamiya-av.htm adresinden alınmıştır.

Global Security. (2011b). Sea Control Ship, 4 Mart 2018'de https:// www.globalsecurity.org/military/systems/ship/scs.htm adresinden alınmıştır.

Global Security. (t.y.). F-35 Joint Strike Fighter (JSF) Lightning II. 7 Eylül 2018'de https://www.globalsecurity.org/military/systems/aircraft/f-35specs.htm adresinden alınmıştır.

Hürriyet. (2017). Erdoğan: Uçak Gemisi Yapacağız. 8 Şubat 2018'de http://www.hurriyet.com.tr/erdogandan-son-dakika-aciklamasi-ucakgemisi-yapacagiz-40507797 adresinden alınmıştır.

Indian Navy. (t.y.). About INS Vikramaditya - The Newest \& Largest Ship of Indian Navy. 17 Şubat 2018'de https://www.indiannavy.nic.in/content/about-insvikramaditya-newest-largest-ship-indian-navy adresinden alınmıştır.

Indian Patriot News. (2018). How Powerful is India's Gigantic INS Vishal Nuclear Powered Aircraft Carrier. 13 Eylül 2018'de http://indianpatriotnews.com/2018/01/05/how-powerful-is-indias-giganticins-vishal-nuclear-powered-aircraft-carrier/ adresinden alınmıştır.

Milliyet. (2016). Erdoğan'dan Nükleer Uçak Gemisi Mesajı. 8 Şubat 2018'de http://www.milliyet.com.tr/erdogan-dan-nukleer-ucak-gemisi-siyaset2236982/ adresinden alınmıştır. 
Naval Technology. (t.y.). Mistral Class - Amphibious Assault Ship. 6 Eylül 2018'de https://www.naval-technology.com/projects/mistral/ adresinden alınmıştır.

Navy Recognition. (2017). Future Indian Navy and French Navy Aircraft Carriers Likelyto be Fitted With EMALS \& AAG. 8 Eylül 2018'de http://www.navyrecognition.com/index.php/news/navalexhibitions/2017/sea-air-space-2017-show-daily-news/5148-future-indiannavy-and-french-navy-aircraft-carriers-likely-to-be-fitted-with-emalsaag.html adresinden alınmıştır.

New Wars. (t.y.). Warship Costs. 4 Eylül 2018'de https://newwars. wordpress.com/warship-costs/ adresinden alınmıştır.

Royal Australian Navy. (t.y.). Amphibious Assault Ship (LHD). 16 Şubat 2018'de http://www.navy.gov.au/fleet/ships-boats-craft/lhd adresinden alınmıştır.

Sabah. (2016). Erdoğan'dan Uçak Gemisi Müjdesi. 8 Şubat 2018'de https:// www.sabah.com.tr/gundem/2016/06/18/erdogandan-ucak-gemisi-mujdesi adresinden alınmıştır.

Save The Royal Navy. (2012). Government U-turn on Carriers Means Less Capability and Long-Term Costs. 5 Eylül 2018'de https://www. savetheroyalnavy.org/government_u-turn_on_carriers/_adresinden alınmıştır.

Savunma Sanayii Müsteşarlığı. (2017). Çok Maksatll Amfibi Hücum Gemisi. 7 Mart 2018'de https://www.ssm.gov.tr/WebSite/ contentlist.aspx? PageID=373\&LangID $=1$ adresinden alınmıştır.

T.C. Dışişleri Bakanlığı. (2006). BN:4 - 25 Temmuz 2006, Lübnan'dan Ülkemize Gerçekleştirilen Tahliye İşlemleri Hk. 6 Eylül 2018 'de http://www.mfa.gov.tr/bn_4---25-temmuz-2006_-lubnan_dan-ulkemizegerceklestirilen-tahliye-islemleri-hk_.tr.mfa adresinden alınmıştır.

Türk Deniz Kuvvetleri. (2015). Türk Deniz Kuvvetleri Stratejisi. 13 Mart 2018'de https://www.dzkk.tsk.tr/data/icerik/392/FLASH/TR/ html5forpc.html?page $=0$ adresinden alınmıştır.

Türk Deniz Kuvvetleri. (t.y.). Platformlar. 13 Mayıs 2018'de https://www. dzkk.tsk.tr/index.php?dil=1\# adresinden alınmıştır. 
United States Navy. (2017). Aircraft Carriers - CVN. 18 Şubat 2018'de http://www.navy.mil/navydata/fact_display.asp?cid=4200\&tid=200\&ct=4 adresinden alınmıştır.

United States Navy. (2018). Amphibious Assault Ships - LHD/LHA(R). 18 Şubat 2018'de http://www.navy.mil/navydata/fact_display.asp?cid= 4200\&tid $=400 \& c t=4$ adresinden alınmıştır. 